\title{
PENGARUH PERILAKU KEPEMIMPINAN DAN KETERAMPILAN MANAJERIAL KEPALA MADRASAH TERHADAP KINERJA GURU DI MAN 1 KOTAMOBAGU
}

\author{
Irwandi Mamonto \\ SMP Satap Badaro \\ Email: mamonto5irwandi@gmail.com \\ Rivai Bolotio \\ Pascasarjana IAIN Manado \\ Email: rivaibolotio@iain-manado.ac.id \\ Ardianto \\ Pascasarjana IAIN Manado \\ Email: ardianto@iain-manado.ac.id
}

\begin{abstract}
Abstrak : Artikel ini bertujuan untuk menguji pengaruh perilaku kepemimpinan dan keterampilan manajerial kepala madrasah terhadap kinerja guru di MAN 1 Kotamobagu. Jenis dan desain penelitian yang digunakan adalah kuantitatif. Pengumpulan data diolah menggunakan teknik statistik deskriptif yang diperoleh dari hasil kuisioner yang telah disebarkan oleh penulis kepada para guru di MAN 1 Kotamobagu. Teknik analisis data yang digunakan yaitu statistik deskriptif dan statistik inferensial. Penelitian ini membuktikan bahwa terdapat pengaruh yang negatif dan tidak signifikan antara perilaku kepemimpinan kepala madrasah dengan kinerja guru di MAN 1 Kotamobagu. Jika dikaitkan dengan keterampilan managerial terhadap kinerja guru di MAN 1 Kotamobagu memiliki pengaruh positif dan tidak signifikan. Maka kinerja guru di MAN I Kotamobagu dipengaruhi oleh keterampilan manajerial kepala sekolah. Sehingga dapat dismpulkan bahwa pengaruh perilaku kepemimpinan dan keterampilan manajerial setelah digabungkan memiliki pengaruh sedikit terhadap kinerja guru di MAN 1 Kotamobagu.
\end{abstract}

\begin{abstract}
This article aims to examine the influence of madrasah principals leadership behavior and managerial skills on teacher performance in MAN 1 Kotamobagu. The type and research design used is quantitative. Data collection was processed using descriptive statistical techniques obtained from the questionnaires distributed by the author to teachers in MAN 1 Kotamobagu. The data analysis technique used is descriptive statistics and inferential statistics. This study proves a negative and insignificant influence between the leadership behavior of madrasah principals and teacher performance in MAN 1 Kotamobagu. If it is associated with managerial skills on teacher performance in MAN 1, Kotamobagu has a positive and insignificant effect. Then the performance of teachers in MAN I Kotamobagu is influenced by the managerial skills of the principal. So it can be concluded that the impact of leadership behavior and managerial skills after being combined has little effect on teacher performance in MAN 1 Kotamobagu.
\end{abstract}

Kata Kunci : Perilaku Kepemimpinan; Keterampilan Manajerial; Kinerja Guru 


\section{Pendahuluan}

Pendidikan secara umum terbagi atas tiga kategori yaitu pendidikan formal, informal dan non formal. Pendidikan formal adalah pendidikan yang kita dapatkan ketika kita sudah berumur 5 tahun ke atas, dimulai dari TK, SD, SMP, SMA dan perguruan tinggi atau disebut dengan pendidikan di lingkungan sekolah. Dari pendidikan formal ini kita memperoleh pengetahuan atau wawasan yang luas baik pengetahuan umum maupun pengetahuan khusus yaitu keagamaan. Pendidikan informal yaitu pendidikan yang kita dapatkan semenjak kita lahir atau disebut dengan pendidikan keluarga. Sedangkan pendidikan nonformal yaitu pendidikan yang kita temui ketika kita berhadapan dengan lingkungan masyarakat luas.

Dari ketiga kategori pendidikan di atas pendidikan yang mampu menunjang kita menjadi manusia yang hakiki terlebih lagi menjadi khalifah dimuka bumi yaitu pendidikan formal atau sekolah, karena dari pendidikan formal ini kita akan memperoleh pengetahuan maupun wawasan yang luas terlebih lagi wawasan yang terkait dengan kepemimpinan. Manusia di amanahkan oleh Allah untuk menjadi khalifah seperti yang di tuangkan Allah SWT di dalam Al-Qur'an, yaitu Q.S. Al-Baqarah : 30.

Ayat tersebut menerangkan bahwa Allah SWT telah mengabarkan kepada malaikat bahwasanya akan Allah SWT ciptakan khalifah dimuka bumi, yakni seorang manusia bernama Adam, dan semua yang nantinya menjadi anak cucu Adam di bumi sebagai penguasa dan yang mengendalikan semuanya. ${ }^{1}$ Walaupun pada dasarnya kita secara tidak langsung sudah memperoleh pendidikan dari orang tua semenjak kecil, tetapi pendidikan yang diberikan oleh orang tua kepada kita diwaktu kecil masih bersifat dasar.

Dapat diketahui bahwa pemimpin berhubungan dengan sekelompok orang yang disebut bawahan untuk mencapai suatu tujuan. Dan dari beberapa pengertian tersebut di atas juga menyimpulkan bahwa kepemimpinan adalah suatu proses mempengaruhi orang lain atau kelompok bawahan guna mencapai tujuan secara efektif dan efisien.

Menjadi seorang pemimpin adalah tanggung jawab yang sangat besar. Di dalam dunia pendidikan atau dunia sekolah pemimpin disuatu sekolah sering disebut dengan kepala sekolah. Kepala sekolah adalah orang yang sangat berperan aktif dalam meningkatkan kualitas sekolah, walaupun disisi lain peran dari guru-guru juga sangat mempengaruhi kemajuan dari suatu pendidikan yang ada di sekolah.

Seorang kepala sekolah sangat dianjurkan untuk mampu mengelola dan mengarahkan bawahannya atau guru-guru untuk mampu memberikan kontribusi yang terbaik bagi sekolah, agar sekolah tersebut bisa diakui keberadaannya oleh pimpinan institusi pendidikan tertinggi dan terlebih khusus masyarakat.

Oleh karena itu manajemen disekolah harus berjalan dengan sebaik mungkin. Ada dua hal menurut saya yang harus dipenuhi oleh seorang manajer atau kepala sekolah yaitu perilaku yang baik dan keterampilan untuk mampu meningkatkan manajemen sekolah. Perilaku adalah suatu sikap yang kita jadikan sebagai suatu acuan penilaian orang lain terhadap kita, baik maupu buruk.

${ }^{1}$ Shalah Abdul Fattah Al-Khalidi, Mudah Tafsir Ibnu Katsir, (Jakarta : Maghfirah Pustaka, 2016), h. 122. 
Perilaku sangatlah penting dalam dunia pendidikan, maka dari pada itu perlu untuk mencantumkan perilaku sebagai salah satu materi penting yang perlu dibahas dan dipraktikkan dikehidupan sehari-hari. Seperti yang dikemukakan oleh salah seorang penulis buku yaitu Mahmud Yunus bahwa dari segi materi, pendidikan Islam terdiri dari pendidikan tauhid, akhlak atau perilaku, ibadah, kesehatan, dan lain sebagainya. ${ }^{2}$

Perilaku yang dianjurkan oleh Al-Qur'an kepada kita yaitu mengarah kepada Rosulullah SAW, karena Rosulullahlah manusia yang dianggap paling berpengaruh di dunia. Dan Rosulullah bukan hanya sukses menjadi pemimpin dalam lingkup kecil seperti sekolah tapi di lingkup yang lebih luas yaitu seluruh dunia. Kesuksesan Rosulullah itu tak lepas dari apa yang diwahyukan kepada Rosulullah yaitu Al-Qur'anul Karim. Karena Al-Qur'anlah yang menjadi buku pedoman atau petunjuk langkah-langkah Rosulullah berperilaku. Bahkan di dalam satu riwayat, istri Rosulullah Aisyah r.a pernah ditanyakan oleh salah satu sahabat berkaitan dengan akhlak Rosulullah, maka istri Rosulullah yaitu Aisyah mengatakan bahwa Akhlak Rosulullah adalah Al-Qur'an.

Maksud dari kata Al-Qur'an merupakan akhlak Rosulullah adalah Rosulullah tidak pernah bertindak maupun berperilaku diluar dari koridor Al-Qur'an. Apa yang diperintahkan di dalam Al-Qur'an itu dijalankan oleh Rosulullah, dan apa yang dilarang di dalam Al-Qur'an itu dijauhi oleh Rosulullah SAW. Oleh karena itu kita dianjurkan untuk meneladani akhlak atau perilaku dari Rosulullah SAW.

Selain perilaku, seorang kepala sekolah atau manajer dituntut harus memiliki kompetensi maupun keterampilan yang layak untuk dijadikan sebagai seorang pemimpin. Suatu keterampilan utama yang diharapkan dari seorang manajer adalah kemampuan berkomunikasi secara efektif. Kesuksesan seorang manajer tergantung dari kemampuannya untuk bekerja sama dengan orang lain, untuk meneruskan ide-ide, menerima saran-saran, dan berusaha membentuk suatu kelompok atau unit kerja untuk mendapatkan informasi yang baik, tepat, dan benar. Oleh karena itu kemampuan komunikasi merupakan hal yang penting bagi manajemen. Karena pentingnya komunikasi tersebut maka Hasibuan mengutip pendapat Henry Klay Lindgreen, mengatakan bahwa kepemimpinan yang efektif berarti komunikasi yang efektif pula. ${ }^{3}$

Rutinitas kepala sekolah menyangkut serangkaian pertemuan interpersonal secara berkelanjutan dengan murid, orang tua, dan terlebih lagi guru. Untuk memenuhi rutinitas di atas, dalam segala hal hendaknya kepala sekolah berpegangan kepada teori bahwa seorang kepala sekolah harusnya bertindak sebagai pembimbing. Teori ini didasarkan pada pengalamannya, karakteristik normatif masyarakat dan sekolah, serta iklim instruksional dan organisasi sekolah. Misalnya, kepala suatu madrasah harus mampu menunjukkan bahwa segala tindakan profesionalnya sesuai dan tidak bertentangan dengan Agama. Hal itu, dapat ditempuh dengan lebih luwes dalam bergaul disamping mengembangkan kompetensi dan kualitas dirinya dalam memimpin suatu sekolah atau madrasah.

Dari uraian di atas dapat kita amati dalam aktifitas di sekolah maupun di luar sekolah yang diperlihatkan oleh kepala sekolah dan guru-guru yang terlibat di sekolah tempat penelitian. Dalam observasi awal yang penulis lakukan di MAN 1 Kotamobagu, bahwa masih terdapat kekurangan dari sekolah yang bersangkutan dari segi kualitas. Kualitas yang

\footnotetext{
${ }^{2}$ Mahmud Yunus, Sejarah Pendidikan Islam, (Jakarta : Hidayakarya Agung, 1989), h. 18.

${ }^{3}$ Marno, Islam by Management and Leadership, (Malang : Lintas Pustaka, 2007), h. 37
} 
dimaksud disini adalah masih terdapat peserta didik yang memiliki pengetahuan di bawah, disebabkan guru yang mengajar tidak optimal dalam memberikan pelajaran kepada peserta didik, karena kurangnya metode maupun strategi guru dalam mengajar atau cara mengajar guru yang monoton, sehingga mengakibatkan kurangnya kemandirian siswa dalam belajar dan kurangnya pengawasan dari kepala sekolah terhadap peserta didik dan guru.

Oleh karena itu, sangat diharapkan sekali agar kepala sekolah mampu membiasakan memberikan bimbingan kepada guru terkait dengan metode pembelajaran agar peserta didik mampu menyerap ilmu yang diberikan, dalam artian baik tetapi harus tegas dalam menjalankan tugas sebagai kepala sekolah. Selain itu kepala sekolah juga diharapkan mampu mendatangkan sesuatu yang baru atau sesuatu yang memiliki dampak positif bagi kemajuan sekolah, seperti pelatihan bagi guru terkait dengan cara atau metode pengelolaan kelas, kemudian pembuatan laporan kemajuan atau perkembangan dari peserta didik di setiap materi pembelajaran, lewat keterampilan dari kepala sekolah, seperti keterampilan dalam berkomunikasi. Untuk itu perlu untuk menguji pengaruh perilaku kepemimpinan.

\section{Metode Penelitian}

Jenis penelitian yang digunakan penulis di dalam penelitian ini adalah kuantitatif. ${ }^{4}$ Dalam penelitian ini, penulis akan mendeskripsikan, menguji, menganalisis dan mengungkapkan korelasi antara perilaku kepemimpinan dan keterampilan manajerial dengan kinerja guru di MAN 1 Kotamobagu.

Penelitian ini berhubungan dengan perilaku kepemimpinan, keterampilan manajerial, dan kinerja guru di MAN 1 Kotamobagu yang bertempat di Kota Kotamobagu, Provinsi Sulawesi Utara yang dilaksanakan selama 60 hari atau 2 bulan lamanya.

Penulis mengambil beberapa unit analisis terhadap 51 orang responden yang berprofesi sebagai guru, yang terdiri dari 32 orang berstatus PNS dan 19 orang berstatus non PNS di MAN 1 Kotamobagu. Penelitian ini dititik beratkan pada perilaku kepemimpinan dan keterampilan manajerial yang telah dilaksanakan oleh kepala madrasah dalam kaitannya dengan peningkatan kinerja guru madrasah yang menjadi obyek penelitian dan penelitian ini adalah penelitian populasi.

Kisi-kisi yang menjadi dasar dalam menyusun butir instrumen perilaku kepemimpinan dituangkan dalam Tabel 1.

Tabel 1. Kisi-kisi dan Indikator Perilaku Kepemimpinan

\begin{tabular}{|c|l|c|c|}
\hline No & \multicolumn{1}{|c|}{ Indikator } & Nomor Butir & Jumlah Butir \\
\hline 1 & $\begin{array}{l}\text { Perilaku atau gaya dalam } \\
\text { memberikan tugas }\end{array}$ & $1,2,3,4,5$ & 5 \\
\hline 2 & $\begin{array}{l}\text { Perilaku atau gaya dalam } \\
\text { hubungan kerja dengan } \\
\text { bawahan }\end{array}$ & $6,7,8,9,10$ & 5 \\
\hline 3 & Situasi kerja & $11,12,13,14,15$ & 5 \\
\hline 4 & Posisi kepemimpinan & $16,17,18,19,20$ & 5 \\
\hline & \multicolumn{1}{|c|}{ Jumlah } & & $\mathbf{2 0}$ \\
\hline
\end{tabular}

${ }^{4}$ Arikunto, Prosedur Penelitian Suatu Pendekatan Praktik, Edisi Revisi ke IV, (Jakarta : PT.Rineka Cipta, 2006), h. 12 
Kisi-kisi dan indikator di atas terdiri dari 20 nomor butir pernyataan, setiap indikator terdapat 5 butir pernyataan. Dan indikator perilaku kepemimpinan terdiri dari 4 indikator, sehingga jumlah keseluruhan butir pernyataan dalam variabel ini berjumlah 20 butir pernyataan.

Selanjutnya kisi-kisi yang menjadi dasar dalam menyusun butir instrumen keterampilan manajerial, yang dituangkan dalam Tabel 2.

Tabel 2. Kisi-kisi dan Indikator Keterampilan Manajerial

\begin{tabular}{|c|c|c|c|}
\hline No & Indikator & Nomor Butir & Jumlah Butir \\
\hline 1 & $\begin{array}{c}\text { Keterampilan } \\
\text { teknik/professional }\end{array}$ & $1,2,3,4,5$ & 5 \\
\hline 2 & Keterampilan pedagogic & $6,7,8,9,10$ & 5 \\
\hline 3 & Keterampilan kepribadian & $11,12,13,14,15$ & 5 \\
\hline 4 & $\begin{array}{c}\text { Keterampilan } \\
\text { kemanusiaan/social }\end{array}$ & $16,17,18,19,20$ & 5 \\
\hline & Jumlah & & $\mathbf{2 0}$ \\
\hline
\end{tabular}

Kisi-kisi dan indikator di atas terdiri dari 20 nomor butir pernyataan, setiap indikator terdapat 5 butir pernyataan. Dan indikator perilaku kepemimpinan terdiri dari 4 indikator, sehingga jumlah keseluruhan butir pernyataan dalam variabel ini berjumlah 20 butir pernyataan.

Kemudian kisi-kisi yang menjadi dasar dalam menyusun butir instrumen kinerja guru adalah konsep Ahmadi yang mengemukakan bahwa kinerja guru adalah separangkat kemampuan yang harus dimiliki oleh guru yang profesional, yaitu: (a) menguasai secara tuntas materi pelajaran yang diajarkannya, (b) mampu memilih dan menerapkan metode yang tepat, (c) dapat memotivasi peserta didik, (d) memiliki keterampilan sosial yang tinggi. Ke empat komponen ini dirinci ke dalam indikator-indikator untuk mengukur kinerja guru antara lain: Loyalitas yang tinggi pada tugas mengajar; Menguasai dan mengembangkan metode; Menguasai bahan pelajaran dan menggunakan sumber belajar; Bertanggung jawab memantau hasil belajar mengajar; Kedisiplinan dalam mengajar dan tugas lainnya; Kreativitas dalam pelaksanaan pengajaran; Melakukan interaksi dengan murid untuk menimbulkan motivasi; Kepribadian yang baik jujur dan obyektif dalam membimbing siswa; Guru mampu berpikir sistematis tentang apa yang dilakukannya; dan Pemahaman dalam administrasi pengajaran. ${ }^{5}$

Tabel 3. Kisi-kisi dan Indikator Kinerja

\begin{tabular}{|c|l|c|c|}
\hline No & \multicolumn{1}{|c|}{ Indikator } & Nomor Butir & Jumlah Butir \\
\hline 1 & $\begin{array}{l}\text { Loyalitas yang tinggi pada tugas } \\
\text { mengajar }\end{array}$ & 1,2 & 2 \\
\hline 2 & $\begin{array}{l}\text { Menguasai dan mengembangkan } \\
\text { metode }\end{array}$ & 3,4 & 2 \\
\hline 3 & $\begin{array}{l}\text { Menguasai bahan pelajaran dan } \\
\text { menggunakan sumber belajar }\end{array}$ & 5,6 & 2 \\
\hline 4 & $\begin{array}{l}\text { Bertanggung jawab memantau } \\
\text { hasil belajar mengajar }\end{array}$ & 7,8 & 2 \\
\hline 5 & Kedisiplinan dalam mengajar dan & 9,10 & \\
\hline
\end{tabular}

5 Ahmadi, Z. A, Kebutuhan Guru dan Tenaga Kependidikan Serta Peningkatan Kualitas Pendidikan, (Jakarta: Depdikbud, 1993), h. 50. 
Journal of Islamic Education Policy Vol. 4 No. 2 Juli - Desember 2019

\begin{tabular}{|c|c|c|c|}
\hline & tugas lainnya & & \\
\hline 6 & $\begin{array}{l}\text { Kreativitas dalam pelaksanaan } \\
\text { pengajaran }\end{array}$ & 11,12 & 2 \\
\hline 7 & $\begin{array}{l}\text { Melakukan interaksi dengan } \\
\text { murid untuk menimbulkan } \\
\text { motivasi }\end{array}$ & 13,14 & 2 \\
\hline 8 & $\begin{array}{l}\text { Kepribadian yang baik jujur dan } \\
\text { obyektif dalam membimbing } \\
\text { siswa }\end{array}$ & 15,16 & 2 \\
\hline 9 & $\begin{array}{l}\text { Guru mampu berpikir sistematis } \\
\text { tentang apa yang dilakukannya }\end{array}$ & 17,18 & 2 \\
\hline \multirow[t]{2}{*}{10} & $\begin{array}{l}\text { Pemahaman dalam administrasi } \\
\text { pengajaran }\end{array}$ & 19,20 & 2 \\
\hline & Jumlah & & 20 \\
\hline
\end{tabular}

Kisi-kisi dan indikator di atas terdiri dari 20 nomor butir pernyataan, setiap indikator terdapat 2 butir pernyataan. Dan variabel kinerja terdiri dari 10 indikator, sehingga jumlah keseluruhan butir pernyataan dalam variabel ini berjumlah 20 butir pernyataan.

Berdasarkan kisi-kisi dan indikator tersebut, maka dikembangkan menjadi angket pertanyaan yang masing-masing telah ditetapkan dengan 5 pilihan jawaban melalui skala likert yaitu : 1. (tidak pernah), 2. (jarang), 3. (kadang), 4. (sering), 5. (selalu).

Tabel 4. Rentang Skala Likert ${ }^{6}$

\begin{tabular}{|c|c|c|}
\hline NO & NILAI & KETERANGAN \\
\hline 1 & 5 & Selalu \\
\hline 2 & 4 & Sering \\
\hline 3 & 3 & Kadang-kadang \\
\hline 4 & 2 & Jarang \\
\hline 5 & 1 & Tidak pernah \\
\hline
\end{tabular}

Berdasarkan hasil perhitungan validitas angket terhadap variabel Perilaku Kepemimpinan $\left(\mathrm{X}_{1}\right)$, Keterampilan Manajerial $\left(\mathrm{X}_{2}\right)$, dan Kinerja Guru (Y) diperoleh bahwa nilai $r_{\text {hitung }}$ untuk semua butir soal yang diuji validitasnya lebih besar dari $r_{\text {tabel }}(>0,2706)$ pada semua variabel penelitian. Dengan demikian, maka semua butir instrument dalam angket penelitian dinyatakan valid dan dapat digunakan untuk analisis selanjutnya. Untuk lebih jelasnya, hasil uji validitas dirangkum pada Tabel 5 .

Tabel 5. Hasil Uji Validitas Perilaku Kepemimpinan

\begin{tabular}{|c|l|c|c|c|l|}
\hline No & \multicolumn{1}{|c|}{ Indikator } & Nomor Butir & Jumlah Butir & Valid & Invalid \\
\hline 1 & Perilaku Tugas & $1,2,3,4,5$ & 5 & 5 & 0 \\
\hline 2 & $\begin{array}{l}\text { Perilaku } \\
\text { Hubungan Kerja }\end{array}$ & $6,7,8,9,10$ & 5 & 5 & 0 \\
\hline 3 & Situasi Kerja & $\begin{array}{c}11,12,13,14,1 \\
5\end{array}$ & 5 & 5 & 0 \\
\hline 4 & $\begin{array}{l}\text { Posisi } \\
\text { Kepemimpinan }\end{array}$ & $\begin{array}{c}16,17,18,19,2 \\
0\end{array}$ & 5 & 5 & 0 \\
\hline & \multicolumn{1}{|l|}{ Jumlah } & & $\mathbf{2 0}$ & $\mathbf{2 0}$ & $\mathbf{0}$ \\
\hline
\end{tabular}

\footnotetext{
${ }^{6}$ Nana Syaodih, Metode Penelitian Pendidikan, (Bandung : Remaja Rosdakarya, 2005), h. 79.
} 
Tabel 6. Hasil Uji Validitas Keterampilan Manajerial

\begin{tabular}{|c|c|c|c|c|c|}
\hline No & Indikator & Nomor Butir & $\begin{array}{c}\text { Jumlah } \\
\text { Butir }\end{array}$ & Valid & Invalid \\
\hline 1 & $\begin{array}{c}\text { Keterampilan } \\
\text { teknik/professional }\end{array}$ & $1,2,3,4,5$ & 5 & 5 & 0 \\
\hline 2 & $\begin{array}{c}\text { Keterampilan } \\
\text { pedagogic }\end{array}$ & $6,7,8,9,10$ & 5 & 5 & 0 \\
\hline 3 & $\begin{array}{c}\text { Keterampilan } \\
\text { kepribadian }\end{array}$ & $11,12,13,14,15$ & 5 & 5 & 0 \\
\hline 4 & $\begin{array}{c}\text { Keterampilan } \\
\text { kemanusiaan/social }\end{array}$ & $16,17,18,19,20$ & 5 & 5 & 0 \\
\hline & Jumlah & & $\mathbf{2 0}$ & $\mathbf{2 0}$ & $\mathbf{0}$ \\
\hline
\end{tabular}

Tabel 7. Hasil Uji Validitas Kinerja

\begin{tabular}{|c|c|c|c|c|c|}
\hline No & Indikator & $\begin{array}{c}\text { Nomor } \\
\text { Butir }\end{array}$ & $\begin{array}{c}\text { Jumlah } \\
\text { Butir }\end{array}$ & Valid & Invalid \\
\hline 1 & $\begin{array}{l}\text { Loyalitas yang tinggi } \\
\text { pada tugas mengajar }\end{array}$ & 1,2 & 2 & 2 & 0 \\
\hline 2 & $\begin{array}{l}\text { Menguasai dan } \\
\text { mengembangkan } \\
\text { metode }\end{array}$ & 3,4 & 2 & 2 & 0 \\
\hline 3 & $\begin{array}{l}\text { Menguasai bahan } \\
\text { pelajaran dan } \\
\text { menggunakan } \\
\text { sumber belajar }\end{array}$ & 5,6 & 2 & 2 & 0 \\
\hline 4 & $\begin{array}{l}\text { Bertanggung jawab } \\
\text { memantau hasil } \\
\text { belajar mengajar }\end{array}$ & 7,8 & 2 & 2 & 0 \\
\hline 5 & $\begin{array}{l}\text { Kedisiplinan dalam } \\
\text { mengajar dan tugas } \\
\text { lainnya }\end{array}$ & 9,10 & 2 & 2 & 0 \\
\hline 6 & $\begin{array}{l}\text { Kreativitas dalam } \\
\text { pelaksanaan } \\
\text { pengajaran }\end{array}$ & 11,12 & 2 & 2 & 0 \\
\hline 7 & $\begin{array}{l}\text { Melakukan interaksi } \\
\text { dengan murid untuk } \\
\text { menimbulkan } \\
\text { motivasi }\end{array}$ & 13,14 & 2 & 2 & 0 \\
\hline 8 & $\begin{array}{l}\text { Kepribadian yang } \\
\text { baik jujur dan } \\
\text { obyektif dalam } \\
\text { membimbing siswa }\end{array}$ & 15,16 & 2 & 2 & 0 \\
\hline 9 & $\begin{array}{l}\text { Guru mampu } \\
\text { berpikir sistematis } \\
\text { tentang apa yang } \\
\text { dilakukannya }\end{array}$ & 17,18 & 2 & 2 & 0 \\
\hline
\end{tabular}


Journal of Islamic Education Policy Vol. 4 No. 2 Juli - Desember 2019

\begin{tabular}{|c|l|c|c|c|c|}
\hline 10 & $\begin{array}{l}\text { Pemahaman dalam } \\
\text { administrasi } \\
\text { pengajaran }\end{array}$ & 19,20 & 2 & 2 & 0 \\
\hline Jumlah & & $\mathbf{2 0}$ & $\mathbf{2 0}$ & $\mathbf{0}$ \\
\hline
\end{tabular}

Tabel 8. Tingkat Keandalan Cronbach

\begin{tabular}{|c|c|}
\hline Interval Nilai & Tingkat Keandalan \\
\hline $0,0-0,20$ & Kurang Andal \\
\hline $0,20-0,40$ & Agak Andal \\
\hline $0,40-0,60$ & Cukup Andal \\
\hline $0,60-0,80$ & Andal \\
\hline $0,80-1,00$ & Sangat Andal \\
\hline
\end{tabular}

Berdasarkan hasil perhitungan reliabilitas angket variabel menggunakan program SPSS v.25, nilai alpha cronbach untuk ketiga variabel penelitian lebih besar dari 0,600 $(>0,600)$ dengan tingkan keandalan instrument sangat andal. Dengan demikian, instrument tersebut dikatakan reliable dan dapat digunakan untuk penelitian. Ringkasan hasil uji reliabilitas instrument dapat dilihat pada Tabel 9.

Tabel 9. Hasil Uji Reliabilitas

\begin{tabular}{|c|c|c|c|}
\hline $\begin{array}{c}\text { Jumlah } \\
\text { Butir Soal }\end{array}$ & Variabel & r $_{\text {hitung }}$ & Keterangan \\
\hline 20 & Perilaku Kepemimpinan & 0,927 & Reliabel \\
\hline 20 & Keterampilan Manajerial & 0,965 & Reliabel \\
\hline 20 & Kinerja Guru & 0,917 & Reliabel \\
\hline
\end{tabular}

Untuk memperoleh data yang dibutuhkan dalam sebuah penelitian, maka penulis harus menggunakan beberapa metode pengumpulan data yaitu kuesioner, sedangkan yang digunakan dalam penelitian ini adalah prosedur pengumpulan data bentuk kuesioner, yang memanfaatkan media online yakni Google Form.

Kuesioner atau angket yang telah dibuat atau disiapkan oleh penulis kemudian disebarkan kepada responden dalam bentuk pernyataan-pernyataan yang berhubungan dengan variabel penelitian yaitu perilaku kepemimpinan, keterampilan manajerial dan kinerja guru di Madrasah Aliyah Negeri 1 Kotamobagu.

Dalam penelitian ini digunakan program aplikasi SPSS V.25 dan Microsoft Excel 2016 untuk membantu analisis data. Metode analisis yang digunakan dalam penelitian ini adalah analisis regresi linier berganda. Analisis ini bertujuan untuk memperoleh gambaran yang menyeluruh mengenai hubungan antara variabel independen dan variabel dependen. Sebelum melakukan uji regresi linier berganda, metode mensyaratkan untuk melakukan uji asumsi klasik yaitu uji normalitas error, uji multikolinearitas, uji non autokorelasi dan uji heteroskidasitas. Uji asumsi dilakukan guna mendapatkan hasil yang terbaik dan tidak bias.

\section{Hasil dan Pembahasan}

Pendidikan diera ini sudah sangat memprihatinkan, dilihat dari segi akhlak baik guru maupun peserta didiknya. Semua yang terjadi dikarenakan kurangnya pengawasan yang baik dari pimpinan dari satu sekolah. Maka diperlukan pemimpin yang mampu mendobrak kebiasaan negatif yang sering terjadi di sekolah, baik kebiasaan negatif dari seorang guru 
maupun peserta didik. Oleh karenanya penulis memandang ini adalah masalah yang penting untuk dibahas dan diangkat dalam satu penelitian terkait dengan perilaku kepemimpinan.

Keberhasilan dari seorang pemimpin atau manajer tak lepas dari kebiasaan atau akhlaknya yang sesuai dengan norma yang berlaku, sehingga membuat orang atau bawahan yang berada disekelilingnya nyaman dalam bekerja maupun beraktivitas. Tapi apabila sebaliknya, maka yang akan terjadi adalah ketidakseriusan bawahan dalam bekerja, banyaknya keluhan dari bawahan dan wibawa kita sebagai pemimpin akan menjadi buruk, dan semua itu akan berdampak pada hasil kerja, yang pada akhirnya tujuan tidak akan tercapai.

Oleh karena itu, diharapkan kepada pemimpin (manajer) yang dalam hal ini adalah kepala sekolah, harus memberikan contoh perilaku atau akhlak yang baik terhadap bawahannya dalam hal ini adalah guru, sehingga terciptanya komunikasi yang baik, kerja sama yang baik, serta hubungan silaturahmi yang baik, yang pada akhirnya berdampak pada hasil kerja atau tujuan yang diharapkan bersama.

Kepemimpinan merupakan salah satu aspek manajerial dalam kehidupan organisasi dan kepemimpinan merupakan inti dari manajemen. Karena dengan adanya kepemimpinan, maka seorang manajer berperan sebagai penyelaras dalam proses kerja sama antar manusia dalam organisasi.

Kepemimpinan adalah gaya atau proses untuk mempengaruhi serta menggerakkan orang lain atau sekelompok orang untuk mencapai suatu tujuan yang telah ditetapkan. ${ }^{7}$ Jadi dapat kita pahami bahwa kepemimpinan suatu model atau kemampuan yang harus dimiliki oleh setiap pemimpin agar mampu mempengaruhi orang lain atau bawahannya, guna mencapai tujuan yang diharapkan.

Kepemipinan itu menyangkut adanya keterlibatan orang lain atau sekelompok orang (pengikut) dalam kegiatan mencapai tujuan, adanya faktor tertentu yang ada pada pemimin sehingga orang lain bersedia digerakkan atau dipengaruhi untuk mencapai tujuan, adanya usaha bersama serta pengarahan berbagai sumber, baik tenaga, dana, waktu, maupun benda. ${ }^{8}$

Sehingga dapat disimpulkan bahwa perilaku kepemimpinan merupakan suatu usaha, seni, maupun kepribadian seseorang yang menyebabkan orang lain patuh, tunduk serta mau mengikuti apa yang diperintahkan kepada mereka, demi mencapai tujuan yang sudah dirumuskan bersama. Demi ambisi mencapai tujuan yang telah ditentukan itu, praktik kepemimpinan dapat dilakukan dengan berbagai cara atau pendekatan, dari yang paling lunak, seperti persuasi, bujukan, ajakan, sugesti, dan sebagainya, sampai yang paling keras seperti menakut-nakuti, menggertak, memaksa, dan sebagainya. Tetapi dalam hal ini seorang manajer atau kepala sekolah diharapkan mampu berlaku baik kepada bawahan dan mampu mengambil keputusan yang bijak dari segala bentuk permasalahan atau perkara yang ditemui di dalam organisasi, institusi atau sekolah yang dipimpin, sehingga tercipta suasana yang asri.

Pendekatan kepemimpinan adalah salah satu faktor yang menentukan kesuksesan seorang pemimpin dalam memimpin suatu kelompok atau organisasi. Istilah ini di dalam ilmu manajemen disebut dengan Human Relation. Human Relation merupakan inti dari kepemimpinan.

\footnotetext{
${ }^{7}$ Ary H. Gunawan, Sosiologi Pendidikan, Jakarta : Rineka Cipta, 2010, h. 123.

${ }^{8}$ Ary H. Gunawan, Sosiologi Pendidika., h. 127.
} 
Ada beberapa teori yang menjelaskan tentang pendekatan yang dilakukan oleh seorang manajer yaitu:

1. Heliriegel dan Slocum, membagi pendekatan kepemimpinan kepada tiga bentuk, yaitu pendekatan model kesifatan (trait model), yang memusatkan pada karakteristik personal pemimpin, pendekatan model perilaku (behavioral model) yang memusatkan pada tindakan pemimpin, pendekatan model kontingensi (contingency model) yang menilai hubungan antara karakteristik dan situasi yang ada dengan pelakuyang dimiliki pemimpin.

2. Wahjosumidjo, menyimpulkan bahwa hampir seluruh penelitian kepemimpinan dapat dikelompokkan ke dalam empat macam pendekatan, yaitu pendekatan pengaruh kewibawaan, pendekatan sifat (traith approach), pendekatan perilaku (behavioral approach), pendekatan situasional (situational approach).

3. Sedangkan menurut James M. Liphans, membagi empat pendekatan histories mengenai analisis kepemimpinan, yaitu pendekatan psikologis (psykologis approach), pendekatan situasional (situational approach), pendekatan perilaku (behavioral approach), pendekatan kontingensi (contingency approah). ${ }^{9}$

Dari penjelasan di atas diharapkan kepada pemimpin atau manajer mampu menjalankan tugas sesuai dengan fungsinya, melalui pengaplikasian pendekatan kepemimpinan yang telah dikemukakan oleh beberapa ahli di atas. Selanjutnya dari seluruh pendekatan yang ada maka pendekatan sifat atau perilaku adalah termasuk salah satu faktor yang menentukan dalam keberhasilan dari seorang pemimpin.

Mengenai pendekatan sifat atau perilaku ini banyak pula pendapat atau teori yang menyebutkan sifat yang harus dimiliki oleh seorang pemimpin. Menurut Keith Davis, ada empat macam kelebihan sifat-sifat yang perlu dimiliki oleh pemimpin atau manajer meliputi, inteligensi, kematangan dan keluasan pandangan sosial, motivasi dan dalam diri individu untuk berprestasi, dan mempunyai kemampuan untuk mengadakan hubungan antar manusia. ${ }^{10}$

Berdasarkan studi Strait Approach yang didukung dengan perkembangan cepat percobaan-percobaan psikologi periode 1920-1950, mengemukakan tiga sifat pribadi seorang pemimpin yaitu, ciri-ciri fisik (physical characteristics), seperti tinggi badan, penampilan dan energi, kepribadian (personality), seperti menjunjung tinggi harga diri, berpengaruh, dan stabilitas emosi, kemampuan/kecakapan (ability), seperti kecerdasan umum, lancar berbicara, keaslian, dan wawasan sosial. ${ }^{11}$

Sementara menurut Gary A Yukl, bahwa sifat-sifat pribadi dan keterampilan seorang pemimpin berdasarkan pendekatan sifat. Sifat-sifat pribadi tersebut diantaranya, Kemampuan menyesuaikan diri terhadap situasi, selalu siap terhadap lingkungan sosial, berorientasi kepada cita-cita dan keberhasilan, kerja sama, mampu mengambil keputusan, berpengaruh/berwibawa, enerjik, gagah, percaya diri, sabar/tahan uji, mau bertanggung jawab. Adapun sifat keterampilan, diantaranya cerdik, konseptual, kreatif, diplomatis dan taktis, lancar berbicara, banyak mengetahui tugas-tugas kelompok, kemampuan mengatur, kemampuan meyakinkan, dan kemampuan berkomunikasi. ${ }^{12}$

\footnotetext{
${ }^{9}$ Ramayulis, Ilmu Pendidikan Islam, (Jakarta : Kalam Mulia, 2002). h. 385.

${ }^{10}$ Keith Davis dalam Bintoro Tjokrominoto, Pengantar Administrasi Pembangunan, (Jakarta : LP3ES, 1974), h. 114

${ }^{11}$ Wahyosumidjo, Kepemimpinan Kepala Sekolah, (Jakarta : PT. Raja Grafindo Persada, 2002), h. 22.

${ }^{12}$ Ramayulis, Ilmu Pendidikan Islam., h. 386.
} 
Dapat ditarik kesimpulan bahwa pendekatan kepemimpinan sangatlah diperlukan dan bersifat urgen bagi setiap pemimpin, terlebih pendekatan sifat atau perilaku. Sesuai dengan beberapa penjelasan di atas pendekatan perilaku atau sifatlah yang utama dari beberapa pendekatan yang lain, karena walaupun kita memiliki pendekatan yang lain dengan sangat baik tapi sifat kita terhadap sesama maupun bawahan kurang baik maka tidak akan terjalin hubungan yang harmonis, dan itu semua pada akhirnya akan menghambat atau mengakibatkan tujuan tidak akan tercapai.

Seorang manajer harus memutuskan untuk menggunakan pendekatan otokratis, demokratis, partisipatif, berorientasi pada tujuan, atau situasional. Pada situasi yang berbeda, manajer yang sama dapat menerapkan gaya kepemimpinan yang berlainan.

Perilaku seorang pemimpin dalam Islam berbeda dengan perilaku seorang pemimpin dalam konsep kepemimpinan secara umum. Hal ini disebabkan bahwa amanah yang diserahkan kepada seorang pemimpin tidak hanya dipertanggung jawabkan di dunia saja, tetapi juga diakhirat. Diantara perilaku yang harus dimiliki seorang pemimpin adalah jujur (al-shidq), adil (al-'adl), dipercaya (al-amanah), Cerdas (al-dzaka) atau al-fathanah, tegas, dan menjaga kehormatan diri (al-muru'ah).

Dalam praktiknya di lapangan, seorang seorang keapal sekolah secara otomatis menjadi seorang menager dalam datu organisasi. Manajer dalam hal ini kepala sekolah senantiasa berhadapan dengan dua alternatif kemungkinan. Pertama, seorang manajer (kepala sekolah) dikatakan berhasil dalam mendidik, dan kedua, seorang manjer (kepala sekolah) dikatakan gagal memimpin. Namun seringkali rasio antara kedua kelompok manajer tersebut seringkali tidak seimbang. Manajer (kepala sekolah) yang berhasil selalu saja lebih sedikit jumlahnya dibandingkan dengan manajer yang gagal atau minimal belum berhasil. Ketidakberhasilan tersebut antara lain disebabkan tidak terpenuhinya syarat-syarat menjadi manajer (kepala sekolah) yang berhasil. Syarat-syarat tersebut demikian banyak dan sangat kompleks serta menuntut kemauan, kerja keras, dan pribadi dari manajer tersebut.

Karena seorang pemimpin adalah publik figur sekaligus penentu dari keberhasilan suatu organisasi. Menjadi seorang pemimpin bukanlah persoalan yang gampang, karena pemimpin merupakan amanah yang akan dimintai pertanggung jawabannya di dunia maupun diakhirat. Oleh karena itu agar amanah pemimpin bisa berjalan sesuai dengan semestinya, maka amanah pemimpin harus diberikan kepada orang yang benar-benar berkompeten dalam ilmu kepemimpinan. Ilmu kepemimpinan antara lain seorang pemimpin harus memiliki keterampilan atau skill dalam menjalankan amanah sebagai pemimpin seperti yang telah dijelaskan.

Keterampilan manajerial dapat dibagi menjadi dua bagian, yaitu hard competence atau hard skill yang terdiri dari kompetensi pedagogik dan kompetensi profesional, dan soft competence atau soft skill yang mencakup kompetensi kepribadian dan kompetensi sosial. Diamana hard skill meliputi keterampilan pedagogik dan profesional atau teknik, sedangkan soft skill terdiri atas keterampilan kepribadian dan keterampilan sosial atau kemanusiaan.

Selain membahas mengenai kepemimpinan dan keterampilan managerial, kinerja guru juga perlu untuk di bahasan karena berkaitan dengan variabel yang akan di gunakan dalam artikel ini. Menurut Veithzal Rivai, konsep kinerja adalah perilaku nyata yang ditampilkan oleh setiap orang sebagai prestasi kerja yang dihasilkan oleh karyawan sesuai dengan perannya dalam perusahaan. ${ }^{13}$ Sedangkan menurut pendapat Ilyas mengatakan bahwa pengertian kinerja adalah penampilan, hasil karya personil baik kualitas, maupun kuantitas

${ }^{13}$ Veithzal Rivai, Manajemen Sumber Daya Manusia Untuk Perusahaan Dari Teori ke Praktek, (Jakarta : PT. Rajagrafindo Persada, 2005), h. 309. 
penampilan individu maupun kelompok kerja personil, penampilan hasil karya tidak terbatas kepada personil yang memangku jabatan fungsional maupun struktural tetapi juga kepada keseluruhan jajaran personil di dalam suatu organisasi atau instansi. ${ }^{14}$

Sehingga dapat ditarik dapat disimpulkan, kinerja meruapakan sebuah penampilan yang mempengaruhi hasil yang dicapai oleh seseorang dalam melaksanakan tugas atau beban kerja maupun tanggung jawab sebagai guru menurut ukuran atau standar yang berlaku pada masing-masing sekolah.

Untuk mengetahui tinggi rendahnya kinerja seseorang, dalam hal ini adalah kinerja dari seorang guru, maka diperlukan suatu pengukuran kinerja. Pengukuran kinerja menurut Simamora adalah suatu alat manajemen untuk meningkatkan kualitas pengambilan keputusan dan akuntabilitas. ${ }^{15}$

Menurut Dharma, pengukuran kinerja harus mempertimbangkan hal-hal berikut: Kuantitas, yaitu jumlah yang harus diselesaikan harus dicapai; Kualitas, yaitu mutu yang harus dihasilkan baik atau tidaknya; dan Ketepatan waktu, yaitu sesuai atau tidaknya dengan waktu yang direncanakan. ${ }^{16}$

Pengukuran kinerja bertujuan untuk melihat perkembangan atau hasil kerja dari seseorang dalam hal ini adalah seorang guru, apakah guru tersebut bekerja dengan baik atau tidak, sehingga dapat dipastikan hasil dari pekerjaan yang dikerjakan oleh guru tersebut.

Setiap instansi atau sekolah harus dapat menyediakan suatu sarana untuk menilai kinerja guru atau bawahan dan hasil penilaian dapat dipergunakan sebagai informasi pengambilan keputusan manajemen tentang kenaikan gaji atau honorarium, penguasaan lebih lanjut, peningkatan kesejahteraan guru, dan berbagai hal penting lainnya yang dapat mempengaruhi guru dalam melaksanakan pekerjaannya.

Penilaian kinerja sangat berguna untuk menentukan kebutuhan pelatihan kerja secara tepat, memberikan tanggung jawab yang sesuai kepada guru sehingga dapat melaksanakan pekerjaan yang lebih baik di masa mendatang dan sebagai dasar untuk menentukan kebijakan dalam promosi jabatan atau kenaikan pangkat dan golongan. Penilaian kinerja memacu pada suatu sistem formal dan terstruktur yang digunakan untuk mengukur, menilai dan mempengaruhi sifat-sifat yang berkaitan dengan pekerjaan yang digeluti.

Menurut Mangkunegara, evaluasi kinerja adalah penilaian yang dilakukan secara sistematis untuk mengetahui hasil pekerjaan karyawan atau bawahan dan kinerja organisasi. ${ }^{17}$ Ada beberapa metode penilaian kinerja bawahan atau karyawan, dalam hal ini terfokus pada guru, dalam suatu sekolah atau organisasi. Menurut pendapat Rivai, yang menyatakan bahwa metode yang dapat digunakan adalah sebagai berikut:

1. Metode penilaian berorientasi pada masa lalu (Skala Peringkat (Rating Scale); Daftar Pertanyaan (Checklist); Metode dengan Penilaian Terarah (Forced Choice Methode); Metode Peristiwa Kritis (Critical Incident Methode); Metode Catatan Prestasi; Skala Peringkat dikaitkan dengan Tingkah Laku; Metode Peninjauan Lapangan (Field Review Methode); Tes dan Observasi Prestasi Kerja (Comparative Evaluation Approach)). ${ }^{18}$

\footnotetext{
${ }^{14}$ Yaslis Ilyas, Kinerja, Teori dan Penelitian, (Yogyakarta : Liberty, 2005), h. 55.

${ }^{15}$ Hendry Simamora, Manajemen Sumber Daya Manusia, (Yogyakarta : STIE.YKPN, 2004), h. 50.

16 Surya Dharma, Manajemen Kinerja. Falsafah, Teori dan Penerapannya, (Yogyakarta : Pustaka Pelajar, 2004), h. 355.

${ }^{17}$ Anwar Prabu Mangkunegara, Manajemen Sumber Daya Manusia Perusahaan, (Bandung : Remaja Rosda Karya, 2005), h. 10.

${ }^{18}$ Veithzal Rivai, Manajemen Sumber Daya Manusia Untuk Perusahaan Dari Teori ke Praktek, h. 325.
} 
2. Metode Penilaian Berorientasi Masa Depan (Penilaian Diri Sendiri (Self Appaisal); Manajemen Berdasarkan Sasaran (Manajemen By Objective); Penilaian Secara Psikologis; Pusat Penilaian (Assessment Center)). ${ }^{19}$

Penilaian kinerja sangatlah penting bagi kemajuan suatu instansi, karena dari hasil penilaian itulah kita dapat melihat bawahan yang menemui kesulitan dalam bekerja atau yang tidak serius dalam bekerja, maupun yang berhasil dalam pekerjaannya, melalui beberapa metode penilaian yang telah dijelaskan. Dipilihlah salah satu atau beberapa metode yang cocok untuk dijadikan sebagai alat ukur keberhasilan kinerja seseorang.

Disamping itu, terdapat dua faktor yang dapat mempengaruhi kenerja seseorang, menurut Mangkunegara, dua faktor tersebut adalah Faktor Kemampuan (ability) dan Faktor Motivasi (Motivation). ${ }^{20}$ Dapat dipahami bahwa yang dapat mempengaruhi suatu kinerja dari seseorang adalah kemampuan atau potensi diri sendiri, karena dengan kemampuan atau potensi yang kita miliki, kita mampu bersaing kerja untuk menghasilkan yang terbaik, dan dengan begitu kinerja kita akan diakui oleh setiap orang yang menjadi rekan kerja kita.

Selain itu ada pula pengaruh yang lain, seperti motivasi. Motivasi ada dua macam, yaitu motivasi dari dalam dan dari luar. Motivasi dari dalam yaitu motivasi yang muncul dari diri kita sendiri, dimana kita mempunyai tekad yang kuat atau berusaha untuk melakukan yang terbaik. Sedangkan motivasi dari luar yaitu motivasi yang datang dari orang lain, dimana orang disekeliling kita memberikan semangat atau dorongan kepada kita, bahwa kita mampu bersaing atau memberikan yang terbaik demi kemajuan bersama.

Pengaruh perilaku kepemimpinan dan keterampilan manajerial adalah dua hal yang dianggap penting yang perlu untuk dimiliki oleh seorang pemimpin dan merupakan unsur penunjang dalam meningkatkan kinerja bawahan dalam hal ini pengaruh kepala sekolah terhadap guru. Jadi pemimpin yang mengawali dengan perilaku dan keterampilan yang baik dalam memimpin suatu organisasi sekolah tentu akan mendapat respon yang baik dari bawahan sehingga memunculkan hasil yang baik berupa kinerja dan kepuasan kerja.

Perilaku kepemimpinan dan keterampilan manajerial memiliki peran yang sangat penting dalam mencapai mutu pendidikan, karena perilaku kepemimpinan dan keterampilan manajerial merupakan unsur terpenting dalam memenuhi kebutuhan manusia untuk menjalani kehidupannya dengan usaha seorang pemimpin tersebut mempengaruhi anggotanya dalam mencapai tujuan organisasi.

Namun kinerja guru dituntut memiliki kemampuan dan merealisasikan harapan dan keinginan semua pihak yang telah mempercayai sekolah dalam hal ini kepala sekolah dan semua guru dalam membina peserta didik. Karena dalam meraih suatu pendidikan yang baik sangat dipengaruhi oleh kinerja guru dalam melaksanakan tugasnya jika kinerja guru tidak baik maka akan berpengaruh terhadap hasil belajar dan minat belajar dari peserta didik. Untuk itu kinerja guru dalam mengajar dituntut harus bisa mencapai tujuan yang telah ditetapkan oleh sekolah. Sebab secara umum mutu pendidikan menjadi tolak ukur bagi keberhasilan dan kemampuan guru.

Berdasarkan pada kajian teori yang telah diuraikan, maka penulis mengajukan hipotesis yang akan diuji kebenarannya dalam penelitian ini, yaitu terdapat pengaruh perilaku kepemimpinan dan keterampilan manajerial kepala madrasah terhadap kinerja guru.

Hasil deskripsi data dari masing-masing variabel, data yang digunakan dalam penelitian perlu diolah lebih lanjut untuk diketahui apakah data yang ada layak digunakan

\footnotetext{
${ }^{19}$ Veithzal Rivai, Manajemen Sumber Daya Manusia Untuk Perusahaan Dari Teori ke Praktek, 326.

${ }^{20}$ Anwar Prabu Mangkunegara, Manajemen Sumber Daya Manusia Perusahaan, h. 13.
} 
dalam analisis atau tidak. Analisis statistika deskriptif dilakukan untuk memberikan gambaran atau deskripsi suatu data yang dilihat dari skor nilai $\mathrm{N}$, nilai rata-rata (Mean), nilai tengah (median), data yang sering muncul/data yang paling banyak (modus), simpangan baku (standard deviation), rentang/jarak (range), total paling sedikit (min), total paling banyak (max), dan total keseluruhan (sum).

Statistika deskriptif dari variabel-variabel yang digunakan pada penelitian ini adalah perilaku kepemimpinan $\left(\mathrm{X}_{1}\right)$, keterampilan manajerial $\left(\mathrm{X}_{2}\right)$, dan kinerja guru $(\mathrm{Y})$, berikut hasil dari uji statistik deskriptif dari setiap variabel:

\section{Variabel $X_{1}$ (Perilaku Kepemimpinan)}

Variabel perilaku kepemimpinan terdiri dari 20 butir soal pernyataan yang telah diuji validitas dan reliabilitasnya. Alternatif jawaban dalam angket variabel $\mathrm{X}_{1}$ terdiri atas 5 pilihan jawaban dengan rentang skor berskala 5-1. dengan demikian skor terendah yang diperoleh setiap responden adalah 59 dan skor tertinggi adalah 100, seperti tertera pada Tabel 10 .

Tabel 10. Data Statistik Deskriptif Variabel $\mathbf{X}_{1}$

\begin{tabular}{|c|c|c|c|c|c|c|c|}
\hline $\mathbf{N}$ & Range & Minimum & Maximum & Sum & Mean & Std. Deviation & Variance \\
\hline 51 & 41 & 59 & 100 & 4474 & 87,725 & 9,765 & 95,363 \\
\hline
\end{tabular}

Sumber :data yang diolah

Selanjutnya untuk menghasilkan deskripsi yang lebih jelas maka akan dibuat suatu tabel penentu kategori. Adapun dalam menentukan kategori interpretasi untuk variabel perilaku kepemimpinan di dasarkan pada skor ideal dengan rumus yang terdapat pada Tabel $11^{21}$

Tabel 11. Rumus penentuan kategori berdasarkan skor ideal variabel $X_{1}$ (Perilaku Kepemimpinan)

\begin{tabular}{|l|l|}
\hline Tinggi & $\mathrm{M}+1 \mathrm{SD} \leq \mathrm{X}$ \\
\hline Sedang & $\mathrm{M}-1 \mathrm{SD} \leq \mathrm{X}<\mathrm{M}+1 \mathrm{SD}$ \\
\hline Rendah & $\mathrm{X}<\mathrm{M}-1 \mathrm{SD}$ \\
\hline
\end{tabular}

Berdasarkan rumus pada Tabel 11, maka diperoleh pedoman untuk mengkategorisasikan tingkat perilaku kepemimpinan sebagaimana dilihat pada Tabel 12 .

Tabel 12. Kategori variabel $X_{1}$ (Perilaku Kepemimpinanl)

\begin{tabular}{|c|c|c|}
\hline No & Interval & Kategori \\
\hline 1 & $\geq 97,49$ & Tinggi \\
\hline 2 & $77,96-97,49$ & Sedang \\
\hline 3 & $\leq 77,96$ & Rendah \\
\hline
\end{tabular}

Sumber :data yang diolah

21 Hanif Akhtar, "Cara Membuat Kategorisasi Data Penelitian dengan Microsoft Excel," Media Elektronik, Semesta Psikometrika, 13 Juli 2020, ttps://www.semestapsikometrika.com/2018/02/membuatkategori-skor-skala-dengan-spss.html?m=1 
Selanjutnya apabila data dimasukan pada kategori berdasarkan Tabel 12, maka akan diperoleh distribusi frekuensi berdasarkan skor sebagaimana tercantum pada Tabel 13.

Tabel 13. Distribusi frekuensi berdasarkan skor

\begin{tabular}{|c|c|c|c|c|}
\hline No & Kategori & Interval & Frekuensi & \% \\
\hline 1 & Tinggi & $\geq 97,49$ & 5 & 10 \\
\hline 2 & Sedang & $77,96-97,49$ & 39 & 76 \\
\hline 3 & Rendah & $\leq 77,96$ & 7 & 14 \\
\hline \multicolumn{3}{|c|}{ Jumlah } & $\mathbf{5 1}$ & $\mathbf{1 0 0}$ \\
\hline
\end{tabular}

Sumber : data yang diolah

Berdasarkan Tabel 13, distribusi frekuensi skor terlihat bahwa guru yang menilai perilaku kepemimpinan pada kategori tinggi sebanyak 5 orang atau sebesar $10 \%$, sedangkan kategori sedang sebanyak 39 orang atau sebesar 76\% dan rendah sebanyak 7 orang atau sebesar $14 \%$. Berdasarkan data tersebut maka dapat diambil kesimpulan bahwa perilaku kepemimpinan kepala madrasah di MAN 1 Kotamobagu berada pada kategori sedang dengan jumlah persentase $76 \%$.

\section{Variabel $\mathbf{X}_{2}$ (Keterampilan Manajerial)}

Variabel keterampilan manajerial terdiri dari 20 butir soal pernyataan yang telah diseleksi dari angket penelitian uji coba. Alternatif jawaban dalam angket variabel $\mathrm{X}_{2}$ terdiri atas 5 pilihan. Rentang skor berskala 5-1, dengan demikian skor terendah yang diperoleh setiap responden adalah 67 dan skor tertinggi adalah 100, seperti tertera pada Tabel 14.

Tabel 14. Data Statistik Deskriptif Variabel $X_{2}$

\begin{tabular}{|c|c|c|c|c|c|c|c|}
\hline N & Range & Minimum & Maximum & Sum & Mean & Std. Deviation & Variance \\
\hline 51 & 33 & 67 & 100 & 4719 & 92,529 & 8,256 & 68,174 \\
\hline
\end{tabular}

Sumber: data yang diolah

Selanjutnya untuk menghasilkan deskripsi yang lebih jelas maka akan dibuat suatu tabel penentu kategori. Adapun dalam menentukan kategori interpretasi untuk variabel keterampilan manajerial di dasarkan pada skor ideal dengan rumus yang terdapat pada Tabel 15 .

Tabel 15. Rumus penentuan kategori berdasarkan skor ideal variabel $X_{2}($ Keterampilan Manajerial)

\begin{tabular}{|l|l|}
\hline Tinggi & $\mathrm{M}+1 \mathrm{SD} \leq \mathrm{X}$ \\
\hline Sedang & $\mathrm{M}-1 \mathrm{SD} \leq \mathrm{X}<\mathrm{M}+1 \mathrm{SD}$ \\
\hline Rendah & $\mathrm{X}<\mathrm{M}-1 \mathrm{SD}$ \\
\hline
\end{tabular}

Berdasarkan rumus di atas, maka diperoleh pedoman untuk mengkategorisasikan tingkat keterampilan manajerial sebagaimana dilihat pada Tabel 16.

Tabel 16. Kategori variabel $X_{2}$ (Keterampilan Manajerial)

\begin{tabular}{|c|c|c|}
\hline No & Interval & Kategori \\
\hline 1 & $\geq 100,78$ & Tinggi \\
\hline 2 & $84,27-100,78$ & Sedang \\
\hline 3 & $\leq 84,27$ & Rendah \\
\hline
\end{tabular}

Sumber : Data Yang Diolah 
Journal of Islamic Education Policy Vol. 4 No. 2 Juli - Desember 2019

Selanjutnya apabila data dimasukan pada kategori di atas, maka akan diperoleh distribusi frekuensi berdasarkan skor sebagaimana tercantum pada Tabel 17.

Tabel 17. Distribusi frekuensi berdasarkan skor

\begin{tabular}{|c|c|c|c|c|}
\hline No & Kategori & Interval & Frekuensi & \% \\
\hline 1 & Tinggi & $\geq 100,78$ & 0 & 0 \\
\hline 2 & Sedang & $84,27-100,78$ & 40 & 78 \\
\hline 3 & Rendah & $\leq 84,27$ & 11 & 22 \\
\hline \multicolumn{2}{|c|}{ Jumlah } & $\mathbf{5 1}$ & $\mathbf{1 0 0}$ \\
\hline
\end{tabular}

Sumber : data yang diolah

Berdasarkan Tabel 17, distribusi frekuensi skor terlihat bahwa guru yang menilai keterampilan manajerial kepala madrasah pada kategori tinggi tidak ada, sedangkan kategori sedang sebanyak 40 orang dengan persentase $78 \%$ dan rendah 11 orang dengan presentase sebesar $22 \%$.

Berdasarkan data tersebut maka dapat diambil kesimpulan bahwa keterampilan manajerial kepala madrasah di MAN 1 Kotamobagu berada pada kategori sedang dengan prsentase sebesar $78 \%$.

\section{Variabel Y (Kinerja Guru)}

Variabel kinerja guru terdiri dari 20 butir soal pernyataan yang telah diseleksi dari angket penelitian uji coba. Alternatif jawaban dalam angket variabel Y terdiri atas 5 pilihan. Rentang skor berskala 5-1, dengan demikian skor terendah yang diperoleh setiap responden adalah 63 dan skor tertinggi adalah 100, seperti tertera pada Tabel 18.

Tabel 18. Data Statistik Deskriptif Variabel Y

\begin{tabular}{|c|c|c|c|c|c|c|c|}
\hline $\mathbf{N}$ & Range & Minimum & Maximum & Sum & Mean & Std. Deviation & Variance \\
\hline 51 & 37 & 63 & 100 & 4587 & 89,941 & 7,566 & 57,256 \\
\hline
\end{tabular}

Sumber : data yang diolah

Selanjutnya untuk menghasilkan deskripsi yang lebih jelas maka akan dibuat suatu tabel penentu kategori. Adapun dalam menentukan kategori interpretasi untuk variabel kinerja guru di dasarkan pada skor ideal dengan rumus yang terdapat pada Tabel 19.

Tabel 19. Rumus penentuan kategori berdasarkan skor ideal variabel Y (Kinerja Guru)

\begin{tabular}{|l|l|}
\hline Tinggi & $\mathrm{M}+1 \mathrm{SD} \leq \mathrm{X}$ \\
\hline Sedang & $\mathrm{M}-1 \mathrm{SD} \leq \mathrm{X}<\mathrm{M}+1 \mathrm{SD}$ \\
\hline Rendah & $\mathrm{X}<\mathrm{M}-1 \mathrm{SD}$ \\
\hline
\end{tabular}

Berdasarkan rumus di atas, maka diperoleh pedoman untuk mengkategorisasikan tingkat kinerja guru sebagaimana dilihat pada Tabel 20.

Tabel 20. Kategori variabel Y (Kinerja Guru)

\begin{tabular}{|c|c|c|}
\hline No & Interval & Kategori \\
\hline 1 & $\geq 97,50$ & Tinggi \\
\hline 2 & $82,37-97,50$ & Sedang \\
\hline 3 & $\leq 82,37$ & Rendah \\
\hline
\end{tabular}

Sumber : Data Yang Diolah 
Selanjutnya apabila data dimasukan pada kategori di atas, maka akan diperoleh distribusi frekuensi berdasarkan skor sebagaimana tercantum pada Tabel 21.

Tabel 21. Distribusi frekuensi berdasarkan skor

\begin{tabular}{|c|c|c|c|c|}
\hline No & Kategori & Interval & Frekuensi & \% \\
\hline 1 & Tinggi & $\geq 97,50$ & 10 & 19,6078 \\
\hline 2 & Sedang & $82,37-97,50$ & 33 & 64,7059 \\
\hline 3 & Rendah & $\leq 82,37$ & 8 & 15,6863 \\
\hline \multicolumn{3}{|c|}{ Jumlah } & 51 & 100 \\
\hline
\end{tabular}

Sumber : data yang diolah

Berdasarkan Tabel 21, distribusi frekuensi skor terlihat bahwa guru yang menilai variabel kinerja guru pada kategori tinggi sebanyak 10 orang dengan persentase sebesar $19,6078 \%$, sedangkan kategori sedang sebanyak 33 orang dengan persentase $64,7059 \%$ dan rendah sebanyak 8 orang dengan presentase $15,6863 \%$.

Berdasarkan data tersebut maka dapat diambil kesimpulan bahwa kinerja guru di MAN 1 Kotamobagu berada pada kategori sedang dengan jumlah presentase sebesar $64,7059 \%$.

\section{Pengujian Persyaratan}

\section{Uji Normalitas}

Uji normalitas error digunakan untuk mengetahui selisih anatar variabel tak bebas $Y$ dan estimasi dari nilai variabel tak bebas Y. dalam hal ini, asumsi normalitas berarti distribusi eror menyebar secara normal dan variabel-variabel bebas tidak harus berdistribusi normal.

Teknik pengujian normalitas eror pada penelitian ini menggunakan one sample test Kolmogorov smirnov. (tambahkan kriteria uji, kapan hasilnya dikatakan normal). Hasil pengujian normalitas error dapat dilihat pada Tabel 22.

\section{Tabel 22. Hasil Uji Normalitas}

\begin{tabular}{|c|c|c|c|}
\hline Uji Statistik & N & $\boldsymbol{p}$ (2-tailed) & Keputusan \\
\hline $\begin{array}{c}\text { One Sample } \\
\text { Kolmogorov-Smirnov }\end{array}$ & 51 & 0,190 & Normal \\
\hline
\end{tabular}

Sumber : data yang diolah

Berdasarkan Tabel 22, diketahui nilai probabilitas (Asymp. Sig. (2-tailed)) adalah 0,190. Karena nilai probabilitas lebih besar dibandingkan tingkat signifikansi 0,05 (0,190>0,05), maka disimpulkan bahwa asumsi normalitas dari error dipenuhi.

\section{Homogenitas}

Uji asumsi homogenitas menurut Edi Riadi digunakan untuk menguji apakah sebaran data dari dua varian atau lebih berasal dari populasi yang homogen atau tidak, yaitu dengan membandingkan dua atau lebih variannya. ${ }^{22}$

Uji homogenitas dilakukan untuk menunjukkan bahwa perbedaan yang terjadi pada uji statistika parametrik benar-benar terjadi akibat adanya perbedaan antar kelompok, bukan sebagai akibat perbedaan dalam kelompok.

\footnotetext{
${ }^{22}$ Edi Riadi, Statistika Penelitian, (Yogyakarta : ANDI, 2016), h. 127.
} 
Journal of Islamic Education Policy Vol. 4 No. 2 Juli - Desember 2019

a. Hasil Uji Asumsi Homogenitas Perilaku Kepemimpinan (X1)

Tabel 23. Uji Homogenitas variabel Perilaku Kepemimpinan

\begin{tabular}{|c|c|c|}
\hline \multicolumn{3}{|c|}{ Test Results } \\
\hline \multicolumn{2}{|c|}{ Box's M } & 5.365 \\
\hline \multirow{2}{*}{ F } & Approx. & 1.286 \\
\cline { 2 - 3 } & df1 & 4 \\
\cline { 2 - 3 } & df2 & 3162.277 \\
\cline { 2 - 3 } & Sig. & .273 \\
\hline $\begin{array}{c}\text { Tests null hypothesis of } \\
\text { equal population } \\
\text { covariance matrices. }\end{array}$ \\
\hline
\end{tabular}

Karena nilai signifikasi Box's $M$ adalah 5,365 dan lebih besar dari nilai taraf signifikasi 0,05, maka disimpulkan bahwa $\mathrm{H}_{0}$ diterima dan $\mathrm{H}_{1}$ ditolak. Maka disimpulkan juga bahwa variabel $\mathrm{X}_{1}$ berasal dari populasi yang homogen.

b. Hasil Uji Asumsi Homogenitas Keterampilan Manajerial

\section{Tabel 24. Uji Homogenitas variabel Keterampilan Manajerial}

\begin{tabular}{|c|c|c|}
\hline \multicolumn{3}{|c|}{ Test Results } \\
\hline \multicolumn{2}{|c|}{ Box's M } & 4.584 \\
\hline \multirow[t]{4}{*}{$\mathrm{F}$} & Approx. & 1.098 \\
\hline & df1 & 4 \\
\hline & df2 & 3162.277 \\
\hline & Sig. & .356 \\
\hline \multicolumn{3}{|c|}{$\begin{array}{l}\text { Tests null hypothesis of } \\
\text { equal population } \\
\text { covariance matrices. }\end{array}$} \\
\hline
\end{tabular}

Karena nilai signifikasi Box's $\mathrm{M}$ adalah 4,584 dan lebih besar dari nilai taraf signifikasi 0,05 , maka disimpulkan bahwa $\mathrm{H}_{0}$ diterima dan $\mathrm{H}_{1}$ ditolak. Maka disimpulkan juga bahwa variabel $\mathrm{X}_{2}$ berasal dari populasi yang homogen. 
c. Hasil Uji Asumsi Homogenitas Kinerja Guru

Tabel 25. Uji Homogenitas variabel Kinerja Guru

\begin{tabular}{|l|l|r|}
\hline \multicolumn{2}{|c|}{ Test Results } \\
\hline \multicolumn{2}{|l|}{ Box's M } & 11.828 \\
\hline \multirow{2}{*}{ F } & Approx. & 2.840 \\
\cline { 2 - 3 } & df1 & \\
\cline { 2 - 3 } & df2 & 3162.277 \\
\cline { 2 - 3 } & Sig. & .023 \\
\hline \multicolumn{2}{|l}{ Tests null hypothesis of } \\
equal population \\
covariance matrices. \\
\hline
\end{tabular}

Karena nilai signifikasi Box's $M$ adalah 11,828 dan lebih besar dari nilai taraf signifikasi 0,05, maka disimpulkan bahwa $\mathrm{H}_{0}$ diterima dan $\mathrm{H}_{1}$ ditolak. Maka disimpulkan juga bahwa variabel Y berasal dari populasi yang homogen.

\section{Uji Non Multikolinearitas}

Untuk mendeteksi apakah terindikasi terjadi gejala multikolinieritas atau tidak, dapat digunakan pendekatan nilai VIF (Variance Inflation Factor) atau nilai tolerance. Nilai VIF dari masing-masing variabel bebas dihitung dengan maksud untuk mendeteksi apakah terindikasi terjadi gejala multikolinieritas atau tidak. Nilai VIF yang lebih besar dari 10 diindikasi terjadi multikolinearitas. Hasil pengujian non multikolinearitas dapat dilihat pada Tabel 26.

Tabel 26. Hasil Uji Non Mulkolinearitas

\begin{tabular}{|c|c|c|c|}
\hline No & Variabel & VIF & Keputusan \\
\hline 1 & Perilaku Kepemimpinan & 3,032 & Tidak terjadi multikolinearitas \\
\hline 2 & Keterampilan Manajerial & 3,032 & Tidak terjadi multikolinearitas \\
\hline
\end{tabular}

Sumber : data yang diolah

Berdasarkan Tabel 26, dapat dilihat bahwa nilai VIF untuk Perilaku Kepemimpinan $\left(\mathrm{X}_{1}\right)$ dan Keterampilan Manajerial $\left(\mathrm{X}_{2}\right)$ adalah 3,032. Karena nilai VIF dari kedua variabel bebas tersebut tidak lebih dari 10, maka disimpulkan tidak terjadi multikolinearitas.

\section{Uji Non Autokorelasi}

Untuk menguji non autokorelasi error dalam penelitian ini menggunakan Uji DurbinWatson. Uji ini dimaksudkan untuk menguji apakah pada model regresi linear ada korelasi antara variabel pengganggu pada $t$ ke periode $t-1$ (satu periode sebelumnya). ${ }^{23}$

${ }^{23}$ Fridayana Yudiaatmaja, Analisis Regresi dengan Menggunakan Aplikasi Komputer Statistik Mi, (Jakarta, PT Gramedia Pustaka Utama, 2013), h.111 


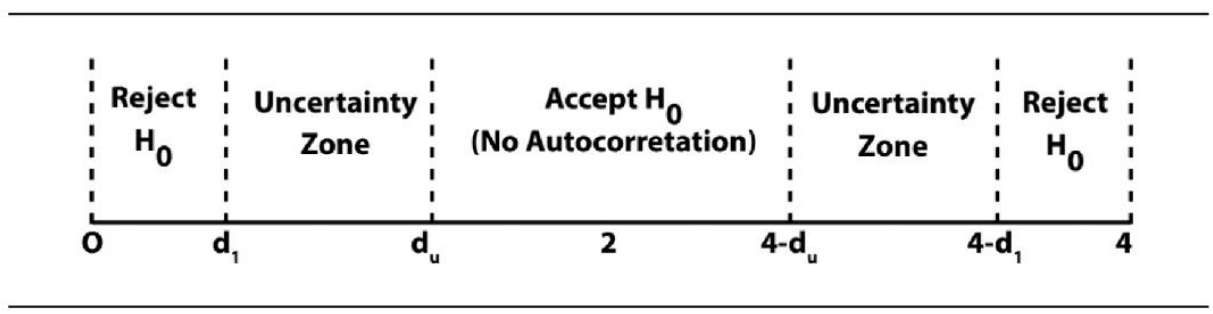

Pada gambar 1 , terdapat istilah $d_{I}$ dan $d_{U}$. istilah $d_{I}$ itu berarti nilai $d_{\text {lower }}$ sedangkan $d_{U}$ berarti $d_{\text {upper }}$, dengan kriteria jumlah data 51, tingkat signifikansi 0,05, dan jumlah variabel bebas 2, Maka dari tabel Durbin-Watson diperoleh $\mathrm{d}_{\mathrm{I}}=1,468$. Dan $\mathrm{d}_{\mathrm{u}}=1,631$. Autokorelasi tidak terjadi bila nilai Durbin-Watson berada antara $d_{U}=1,631$ dan $\left(4-d_{U}=2,369\right)$. Hasil pengujian non autokorelasi dapat dilihat pada Tabel 27.

\section{Tabel 27. Hasil Uji Autokorelasi}

\begin{tabular}{|c|c|c|}
\hline Uji Statistik & Nilai Durbin-Watson & Keputusan \\
\hline Uji Durbin-Watson & $2,002$. & non-autokorelasi dipenuhi \\
\hline
\end{tabular}

Sumber : data yang diolah

Berdasarkan Tabel 27, dapat dilihat bahwa nilai statistik dari uji Durbin-Watson adalah 1,852. Karena nilai statistik dari uji Durbin-Watson berada di antara $4-\mathrm{d}_{\mathrm{U}}=2,369$ dan $\mathrm{d}_{\mathrm{l}}=1,468$, maka disimpulkan bahwa asumsi independensi dari error atau non-autokorelasi dipenuhi.

\section{Uji Homoskedastisitas}

Ketika asumsi homoskedastisitas tidak dipenuhi, maka peristiwa tersebut disebut heteroskedastisitas. Untuk mendeteksi terjadinya gejala heteroskedastisitas dilakukan dengan uji glejser. Jika terdapat koefisien regresi $b$ yang signifikan secara statistika (statistically significant), maka diindikasi terjadi heteroskedastisitas. Namun jika tidak terdapat koefisien regresi $b$ yang signifikan secara statistika (statistically significant), maka asumsi homoskedastisitas dipenuhi Hasil pengujian homoskidasitas dapat dilihat pada Tabel 28.

Tabel 28. Hasil Uji Homoskedastisitas

\begin{tabular}{|c|c|c|c|}
\hline Variabel Bebas & Uji Statistik & $\boldsymbol{P}$ & Keputusan \\
\hline Ln $X_{1}$ & Uji Glejser & 0,882 & \\
\hline Ln $X_{2}$ & Uji Glejser & 0,088 & \\
\hline
\end{tabular}

Sumber :data yang diolah

Berdasarkan Uji Glejser pada Tabel 28. nilai probabilitas (Sig) untuk koefisien regresi dari variabel $1 n \_X_{1}$ dan $l n \_X_{2}$ masing-masing adalah 0,882 dan 0,088. karena nilai-nilai probabilitas tersebut lebih besar dari tingkat signifikansi $\alpha=0,05$, maka disimpulkan bahwa tidak terjadi heteroskedastisitas. Dengan kata lain, asumsi mengenai homoskedastisitas dipenuhi.

\section{Pengujian Hipotesis}

Pengajuan hipotesis dilakukan untuk mengetahui ada atau tidaknya hubungan antar variabel bebas dengan variabel terikat. Pengujian hipotesis dalam penelitian ini menggunakan analisis linear berganda dengan teknik analisis uji koefisien determinasi $R^{2}$, uji simultan $F$, dan uji parsial $\mathrm{T}$. dalam pengjian hipotesis ini penulis menggunkan bantuan program IBM SPSS dan Microsoft Excel. 


\section{Persamaan Regresi Linier Sederhana}

Analisis linear sederhana dalam penelitian ini digunakan untuk menjawab hipotesis apakah perilaku kepemimpinan berpengaruh terhadap kinerja guru dan apakah keterampilan manajerial kepala madrasah berpengaruh terhadap kinerja guru.

a. Uji Regresi Sederhana Variabel $\mathrm{X}_{1}$ dengan $\mathrm{Y}$

1. Persamaan Regresi Linier Sederhana

\begin{tabular}{|c|c|c|c|c|c|c|}
\hline \multicolumn{7}{|c|}{ Coefficients $^{\mathrm{a}}$} \\
\hline \multirow{2}{*}{\multicolumn{2}{|c|}{ Model }} & \multicolumn{2}{|c|}{$\begin{array}{l}\text { Unstandardized } \\
\text { Coefficients }\end{array}$} & \multirow{2}{*}{$\begin{array}{c}\begin{array}{c}\text { Standardized } \\
\text { Coefficients }\end{array} \\
\text { Beta }\end{array}$} & \multirow[b]{2}{*}{$\mathrm{t}$} & \multirow[b]{2}{*}{ Sig. } \\
\hline & & $\mathrm{B}$ & Std. Error & & & \\
\hline \multirow[t]{2}{*}{1} & (Constant) & 69.792 & 9.330 & & 7.480 & .000 \\
\hline & $\mathrm{X} 1$ & .230 & .106 & .296 & 2.173 & .035 \\
\hline
\end{tabular}

a. Dependent Variable: Y

2. Uji Linearitas Garis Regresi

$$
\mathrm{Y}=69.792+0.23 \mathrm{X}_{1}
$$

\begin{tabular}{|l|l|r|r|r|r|r|}
\hline \multicolumn{2}{|c|}{ ANOVA Table } \\
\hline \multicolumn{2}{|c|}{} & $\begin{array}{l}\text { Sum of } \\
\text { Squares }\end{array}$ & \multicolumn{1}{c|}{ df } & $\begin{array}{c}\text { Mean } \\
\text { Square }\end{array}$ & \multicolumn{1}{c|}{ F } & \multicolumn{1}{c|}{ Sig. } \\
\hline \multirow{2}{*}{ Between Groups } & (Combined) & 1422.157 & 23 & 61.833 & 1.159 & .354 \\
\cline { 2 - 8 } & Linearity & 251.546 & 1 & 251.546 & 4.714 & .039 \\
\cline { 2 - 8 } & $\begin{array}{l}\text { Deviation } \\
\text { from } \\
\text { Linearity }\end{array}$ & 1170.611 & 22 & 53.210 & .997 & .497 \\
\hline Within Groups & & 1440.667 & 27 & 53.358 & & \\
\hline Total & 2862.824 & 50 & & & \\
\hline
\end{tabular}

3. Uji Signifikansi Korelasi

\begin{tabular}{|l|l|r|r|}
\hline \multicolumn{3}{|c|}{ Correlations } \\
\hline \multirow{3}{*}{ X1 } & $\begin{array}{l}\text { Pearson } \\
\text { Correlation }\end{array}$ & \multicolumn{1}{|c|}{ X1 } & \multicolumn{1}{c|}{ Y } \\
\cline { 2 - 4 } & Sig. (2-tailed) & $.296^{*}$ \\
\cline { 2 - 4 } & N & 51 & .035 \\
\hline Y & $\begin{array}{l}\text { Pearson } \\
\text { Correlation }\end{array}$ & $.296^{*}$ & 51 \\
\cline { 2 - 4 } & Sig. (2-tailed) & .035 & \\
\cline { 2 - 4 } & N & 51 & 51 \\
\hline
\end{tabular}

Jadi bisa kita amati dari data di atas korelasi pearson yang diperoleh adalah sebesar 0,296 dengan nilai sig 0,035 yang berarti korelasi signifikan antara $\mathrm{X}_{1}$ dan $\mathrm{Y}$. 
Journal of Islamic Education Policy Vol. 4 No. 2 Juli - Desember 2019

b. Uji Regresi Sederhana Variabel $\mathrm{X}_{2}$ dengan $\mathrm{Y}$

1. Persamaan Garis Regresi

\begin{tabular}{|c|c|c|c|c|c|c|}
\hline \multicolumn{7}{|c|}{ Coefficients $^{\mathrm{a}}$} \\
\hline \multirow{2}{*}{\multicolumn{2}{|c|}{ Model }} & \multicolumn{2}{|c|}{$\begin{array}{l}\text { Unstandardized } \\
\text { Coefficients }\end{array}$} & \multirow{2}{*}{$\begin{array}{c}\begin{array}{c}\text { Standardized } \\
\text { Coefficients }\end{array} \\
\text { Beta } \\
\end{array}$} & \multirow[b]{2}{*}{$\mathrm{t}$} & \multirow[b]{2}{*}{ Sig. } \\
\hline & & $\mathrm{B}$ & Std. Error & & & \\
\hline \multirow[t]{2}{*}{1} & (Constant) & 58.057 & 11.269 & & 5.152 & .000 \\
\hline & $\mathrm{X} 2$ & .345 & .121 & .376 & 2.840 & .007 \\
\hline
\end{tabular}

a. Dependent Variable: Y

$$
\mathrm{Y}=58.057+0.345 \mathrm{X}_{2}
$$

2. Uji Linearitas Garis Regresi

\begin{tabular}{|c|c|c|c|c|c|c|c|}
\hline \multicolumn{8}{|c|}{ ANOVA Table } \\
\hline & & & $\begin{array}{l}\text { Sum of } \\
\text { Squares }\end{array}$ & $\mathrm{df}$ & $\begin{array}{l}\text { Mean } \\
\text { Square }\end{array}$ & $\mathrm{F}$ & Sig. \\
\hline \multirow{5}{*}{$\begin{array}{l}\mathrm{Y}^{*} \\
\mathrm{X} 2\end{array}$} & \multirow{3}{*}{$\begin{array}{l}\text { Between } \\
\text { Groups }\end{array}$} & (Combined) & 973.774 & 18 & 54.099 & .916 & .566 \\
\hline & & Linearity & 404.745 & 1 & 404.745 & $\begin{array}{r}6.85 \\
6\end{array}$ & .013 \\
\hline & & $\begin{array}{l}\text { Deviation } \\
\text { from } \\
\text { Linearity }\end{array}$ & 569.028 & 17 & 33.472 & .567 & .892 \\
\hline & \multicolumn{2}{|c|}{ Within Groups } & 1889.050 & 32 & 59.033 & & \\
\hline & \multicolumn{2}{|l|}{ Total } & 2862.824 & 50 & & & \\
\hline
\end{tabular}

3. Uji Signifikansi Korelasi

\begin{tabular}{|c|c|c|c|}
\hline \multicolumn{4}{|c|}{ Correlations } \\
\hline & & $\mathrm{X} 2$ & Y \\
\hline \multirow[t]{3}{*}{$\mathrm{X} 2$} & $\begin{array}{l}\text { Pearson } \\
\text { Correlation }\end{array}$ & 1 & $.376^{* * *}$ \\
\hline & Sig. (2-tailed) & & .007 \\
\hline & $\mathrm{N}$ & 51 & 51 \\
\hline \multirow[t]{3}{*}{$Y$} & $\begin{array}{l}\text { Pearson } \\
\text { Correlation }\end{array}$ & $.376^{* *}$ & 1 \\
\hline & Sig. (2-tailed) & .007 & \\
\hline & $\mathrm{N}$ & 51 & 51 \\
\hline
\end{tabular}

Jadi bisa kita amati dari data di atas korelasi pearson yang diperoleh adalah sebesar 0,376 dengan nilai sig 0,007 yang berarti korelasi signifikan antara $\mathrm{X}_{1}$ dan $\mathrm{Y}$.

\section{Persamaan Regresi Linear Berganda}

Analisis linear berganda dalam penelitian ini digunakan untuk menjawab hipotesis apakah perilaku kepemimpinan dan keterampilan manajerial kepala madrasah berpengaruh secara simultan maupun parsial berpengaruh terhadap kinerja guru. 
Irwandi Mamonto, Rivai Bolotio \& Ardianto : Pengaruh Perilaku Kepemimpinan

Tabel 29. Hasil analisis linear berganda

\begin{tabular}{|c|l|c|}
\hline No & \multicolumn{1}{|c|}{ Model } & B \\
\hline 1 & Konstanta & 58,007 \\
\hline 2 & Perilaku Kepemimpinan & $-0,027$ \\
\hline 3 & Keterampilan Manajerial & 0,371 \\
\hline
\end{tabular}

Sumber : data yang diolah

Berdasarkan Tabel 29 diperoleh nilai koefisien konstanta sebesar 58,007 koefisien perilaku kepemimpinan sebesar -0,027, koefisien keterampilan manajerial 0,371. maka persamaan regresi dapat dirumuskan sebagai berikut :

$$
\hat{Y}=58,007-0,027 X_{1}+0,371 X_{2}
$$

\section{Uji Koefisien Determinasi $\left(\mathbf{R}^{2}\right)$}

Untuk mengukur kemampuan model regresi linear dalam mencocokkan atau menyesuaikan (fits) data. Nilai koefisien determinasi berkisar antara 0 dan 1 . Nilai koefisien determinasi yang semakin dekat dengan 1 menunjukkan semakin baik kemampuan model regresi linear dalam mencocokkan atau menyesuaikan (fits) data. Dengan kata lain kemampuan variabel-variabel bebas dalam menjelaskan variation variabel tak bebas semakin baik. Hasil pengujian koefisiens determinasi $r^{2}$ dapat dilihat pada Tabel 30.

Tabel 30. Hasil uji determinasi $\mathbf{r}^{2}$

\begin{tabular}{|c|c|c|c|}
\hline Model Regresi & $\boldsymbol{R}$ & $\boldsymbol{r}^{\mathbf{2}}$ & $\boldsymbol{\%}$ \\
\hline Linear Berganda & 0,376 & 0,141 & 14,1 \\
\hline
\end{tabular}

Sumber : data yang diolah

Dari Tabel 30, diketahui nilai koefisien determinasi atau $r^{2}$ adalah 0,141. Nilai tersebut dapat diinterpretasikan sebagai variabel perilaku kepemimpinan dan keterampilan manajerial kepala madrasah mampu menjelaskan atau menerangkan variation dari variabel kinerja guru sebesar $14,1 \%$, sisanya sebesar $85,9 \%$ dijelaskan oleh variabel-variabel lain.

\section{Uji Simultan (Uji F)}

Uji $\mathrm{F}$ dalam penelitian ini digunakan untuk melihat ada atau tidaknya pengaruh variabel bebas (Perilaku Kepemimpinan dan Keterampilan Manajerial Kepala Madrasah) terhadap variabel terikat (Kinerja Guru) secara bersama-sama.

Pengambilan keputusan terhadap hipotesis dalam penelitian ini dilakukan dengan menggunakan pendekatan nilai probabilitas dari uji $F$. Nilai probabilitas dari uji $F$ dibandingkan dengan tingkat signifikansi yang digunakan. Pengambilan keputusan terhadap hipotesis dilakukan berdasarkan pendekatan nilai probabilitas. $\mathrm{H}_{0}$ ditolak jika nilai probabilitas lebih kecil dari tingkat signifikansi $(p<0,05)$ dan $\mathrm{H}_{0}$ diterima jika nilai probabilitas lebih besar atau sama dengan tingkat signifikansi $(p \geq 0,05)$. Hasil pengujian Uji F dapat dilihat pada Tabel 31. 
Tabel 31. Hasil Uji F

\begin{tabular}{|c|c|c|c|c|c|}
\hline Uji Statistik & $d f_{\text {total }}$ & $F_{\text {hitung }}$ & $F_{\text {tabel }}$ & $P$ & Keputusan \\
\hline Uji F & 50 & 3,964 & 3,191 & 0,025 & $\mathrm{H}_{0}$ ditolak \\
\hline
\end{tabular}

\section{Sumber :data yang diolah}

Berdasarkan Tabel 31, diketahui nilai probabilitas (Sig) 0,025. Karena nilai probabilitas tersebut lebih kecil dibandingkan $\alpha=0,05$, maka hipotesis nol ditolak dan hipotesis alternatif diterima. Hal ini berarti paling tidak terdapat satu variabel bebas yang memiliki pengaruh signifikan secara statistika terhadap variabel kinerja guru.

\section{Uji Parsial (Uji t)}

Tujuan dari uji parsial adalah untuk mengetahui seberapa jauh pengaruh dari variabel independen $(\mathrm{X})$ terhadap variabel dependen $(\mathrm{Y})$ secara parsial. Sebelum menghitung nilai kritis $t$, terlebih dahulu menghitung nilai derajat bebas. Berikut rumus untuk menghitung nilai derajat bebas.

\section{Derajat bebas $=n-k$.}

$n$ menyatakan jumlah elemen dalam sampel, sedangkan $k$ merupakan jumlah variabel. Jumlah elemen dalam sampel sebanyak 51 dan jumlah variabel adalah 3 (jumlah variabel bebas adalah 2 dan variabel tak bebas adalah 1), sehingga derajat bebas adalah $51-3=48$. Tingkat signifikansi yang digunakan adalah 5\%, sehingga nilai kritis $t$ dengan derajat bebas 48 dan tingkat signifikansi $5 \%$ berdasarkan tabel distribusi $t$ adalah 1,660 . Hasil pengujian Uji T dapat dilihat pada Tabel 32.

Tabel 32. Hasil Uji T

\begin{tabular}{|c|c|c|c|c|c|c|c|}
\hline \multirow{2}{*}{ No } & \multicolumn{3}{|c|}{ Variabel } & \multirow{2}{*}{$\boldsymbol{R}$} & \multirow{2}{*}{$r^{2}$} & \multirow{2}{*}{$\%$} & \multirow{2}{*}{$\begin{array}{c}\text { Keterangan } \\
\text { Hubungan }\end{array}$} \\
\hline & Bebas & Terikat & Kontrol & & & & \\
\hline 1 & $\mathrm{X}_{1}$ & $\mathrm{Y}$ & $\mathrm{X}_{2}$ & $-0,021$ & 0.0004 & 0,04 & Tidak Kuat \\
\hline 2 & $\mathrm{X}_{2}$ & $\mathrm{Y}$ & $\mathrm{X}_{1}$ & 0,243 & 0.059 & 5.9 & Cukup Kuat \\
\hline
\end{tabular}

Sumber : data yang diolah

Berdasarkan Tabel 32, dapat dilihat bahwa perilaku kepemimpinan memiliki keeratan hubungan dengan kinerja guru sebesar - 0,021 , dengan mengontrol pengaruh dari keterampilan manajerial kepala madrasah, nilai korelasi parsial tersebut mendekati 0 sehingga keeratan hubungan yang terjadi tidak terlalu kuat. Sementara itu, berdasarkan Tabel 32 dapat dilihat bahwa keterampilan manajerial kepala madrasah memiliki keeratan hubungan dengan kinerja guru sebesar 0,243, dengan mengontrol pengaruh dari perilaku kepemimpinan, nilai korelasi parsial tersebut mendekati 1 sehingga keeratan hubungan yang terjadi cukup kuat.

Untuk lebih memperjelas hubungan antara variabel maka akan dilakukan uji signifikasi regresi secara individu dengan Uji t. Pengujian dilakukan dengan mengontrol pengaruh salah satu variabel. $\mathrm{H}_{0}$ ditolak jika nilai probabilitas lebih kecil dari tingkat signifikansi $(p<0,05)$ dan $\mathrm{H}_{0}$ diterima jika nilai probabilitas lebih besar atau sama dengan tingkat signifikansi $(p \geq 0,05)$.

Jika nilai sig $<0,05$ maka terdapat pengaruh variabel $\mathrm{X}$ terhadap variabel $\mathrm{Y}$ secara parsial

Jika nilai sig $>0,05$ maka tidak terdapat pengaruh variabel $\mathrm{X}$ terhadap variabel $\mathrm{Y}$ secara parsial 
Hasil pengujian uji T dapat dilihat pada Tabel 33.

Tabel 33. Hasil Uji Signifikasi Uji T

\begin{tabular}{|c|c|c|c|c|c|c|c|}
\hline \multirow{2}{*}{ No } & \multicolumn{3}{|c|}{ Variabel } & \multirow{2}{*}{$t_{\text {hitung }}$} & \multirow{2}{*}{$t_{\text {kritis }}$} & \multirow{2}{*}{$\boldsymbol{P}$} & \multirow{2}{*}{ Keputusan } \\
\hline & Bebas & Terikat & Kontrol & & & & \\
\hline & $\mathrm{X}_{1}$ & Y & $\mathrm{X}_{2}$ & $-2,683$ & 1,983 & 0,004 & Tidak berpengaruh \\
\hline & $\mathrm{X}_{2}$ & $Y$ & $X_{1}$ & 2,371 & 1,983 & 0,912 & Berpengaruh \\
\hline
\end{tabular}

Sumber :data yang diolah (lihat Lampiran)

Berdasarkan Tabel 33, Nilai siginifikansi dari uji $t$ untuk variable perilaku kepemimpinan adalah 0,004. Karena 0,004 $<0,05$ maka disimpulkan bahwa dengan mengontrol pengaruh keterampilan manajerial kepala madrasah, variabel perilaku kepemimpinan tidak mempengaruhi kinerja guru secara signifikan (signifikan secara statistika). Sementara itu, nilai signifikansi uji $t$ untuk variabel keterampilan manajerial kepala madrasah adalah 0,912. Karena 0,912 > 0,05, maka disimpulkan bahwa dengan mengontrol perilaku kepemimpinan, variabel keterampilan manajerial kepala madrasah mempengaruhi kinerja guru secara signifikan (signifikan secara statistika).

\section{Analisis Lanjut}

Sumbangan relatif digunakan untuk mengetahui besarnya sumbangan masing-masing variabel bebas atau predictor terhadap prediksi. Sedangkan sumbangan efektif digunakan untuk mengetahui sumbangan efektif tiap predictor atau variabel bebas dari keseluruhan prediksi. Hasil pengujian SR dan SE dapat dilihat pada Tabel 34.

Tabel 34. Hasil Uji SR dan SE

\begin{tabular}{|c|c|c|c|}
\hline \multirow{2}{*}{ No } & \multirow{2}{*}{ Variabel } & \multicolumn{2}{|c|}{ Sumbangan } \\
\cline { 3 - 4 } & & Relatif & Efektif \\
\hline 1 & $\mathrm{X}_{1}$ & $-7 \%$ & $8,76 \%$ \\
\hline 2 & $\mathrm{X}_{2}$ & $127 \%$ & $14,14 \%$ \\
\hline \multicolumn{2}{|c|}{ Jumlah } & $120 \%$ & $13 \%$ \\
\hline
\end{tabular}

Sumber : data yang diolah

Dari Tabel 34, sumbangan relatif masing-masing variabel bebas atau predictor terhadap prediksi yaitu varibel $\mathrm{X}_{1}-7 \%$ dan $\mathrm{X}_{2} 127 \%$, sedangkan sumbangan efektif yaitu $13 \%$.

\section{Pengaruh Perilaku Kepemimpinan dan Keterampilan Manajerial Kepala Madrasah Terhadap Kinerja Guru di MAN 1 Kotamobagu}

Berdasarkan hasil analisis, penelitian ini menunjukkan pengaruh yang positif dan signifikan antara perilaku kepemimpinan dan keterampilan manajerial kepala madrasah dengan kinerja guru di MAN 1 Kotamobagu. Hasil perhitungan menggunakan analisis regresi linear berganda menunjukan bahwa koefisien variabel perilaku kepemimpinan pada model persamaan regresi adalah $\hat{Y}=58,007-0,027 X_{1}+0,371 X_{2}$. Hal tersebut menunjukkan bahwa variabel perilaku kepemimpinan dan keterampilan manajerial kepala madrasah berpengaruh terhadap variabel kinerja guru.

Melalui analisis korelasi Uji f, nilai probabilitas dari uji $F$ dibandingkan dengan tingkat signifikansi yang digunakan yaitu nilai probabilitas (Sig) 0,025. Karena nilai probabilitas tersebut lebih kecil dibandingkan $\alpha=0,05$, hal ini berarti terdapat hubungan yang 
positif dan signifikan antara perilaku kepemimpinan dan keterampilan manajerial kepala madrasah dengan kinerja guru di MAN 1 Kotamobagu.

Dalam hasil analisis, dijelaskan bahwa terdapat pengaruh yang positif dan signifikan antara perilaku kepemimpinan dan keterampilan manajerial kepala madrasah terhadap kinerja guru di MAN 1 Kotamobagu. Hal ini dikarenakan dalam satuan pendidikan kepala sekolah menduduki dua jabatan penting untuk bisa menjamin kelangsungan proses pendidikan sebagaimana telah digariskan oleh peraturan perundang-undangan. Pertama, kepala sekolah adalah pengelola (Manajer) disekolah secara keseluruhan. Kedua, kepala sekolah adalah pemimpin formal pendidikan di sekolah.

Sebagai pengelola pendidikan kepala sekolah bertanggung jawab terhadap keberhasilan penyelenggaraan kegiatan pendidikan dengan cara melaksanakan administrasi di sekolah denganseluruh subtansinya. Disamping itu, kepala sekolah bertanggung jawab terhadap kualitas sumber daya manusia yang ada agar mereka mampu menjalankan tugastugas pendidikan. Oleh karena itu, sebagai pengelola (Manajer) kepala sekolah memiliki tugas untuk mengembangkan kinerja para personal yaitu guru-guru kearah profesinalisme yang di harapkan.

Sebagai pemimpin formal kepala sekolah bertanggung jawab atas tercapainya tujuan pendidikan melalui upaya menggerakan para bawahan kearah pencapaian tujuan pendidikan yang telah ditetapkan. Dalam hal ini kepala sekolah bertugas melaksanakan fungsi-fungsi kepemimpinan, baik fungsi yang berhubungan dengan pencapaian tujuan pendidikan maupun penciptaan iklim sekolah yang kondusif bagi terlaksananya proses belajar menhgajar yang efektif dan efisien.

Dari penjalasn di atas dapat kita pahami bahwa dua peran kepala sekoalh tersebut seperti dua sisi mata uang yang tidak dapat dipisahkan karena tanpa kemampuan manajerial, seoarang pemimpin akan kesulitan menetapkan langkah-langkah kerja rasioanal yang didasari oleh nilai teoritis pengembangan organisasi. Begitupun sebaliknya seorang seorang manajer tidak memilki kemampuan memimpin maka lambat laun organisasi akan kehilangan pamornya karena tidak ada orang yang dijadikan rujukan, memberikan motivasi dan menentukan arah organisasi.

Sehubungan dengan penelitian terdahulu antara perilaku kepemimpinan dan keterampilan manajerial kepala madrasah pengaruhnya terhadap kinerja guru di sekolah di MTs Negeri 1 Bolaang Mongondow Timur. Hasil perhitungan menggunakan analisis regresi linear berganda menunjukan bahwa koefisien variabel perilaku kepemimpinan pada model persamaan regresi adalah $\hat{Y}=44,455+0,632 X_{1}+(-0,039) X_{2}$. Hal tersebut menunjukkan bahwa variabel perilaku kepemimpinan dan keterampilan manajerial kepala madrasah memberikan sumbangsih terhadap variabel kinerja guru.

Melalui uji $\mathrm{F}$, nilai probabilitas dari uji $F$ dibandingkan dengan tingkat signifikansi yang digunakan yaitu nilai probabilitas ( $\mathrm{Sig}$ ) 0,000. Karena nilai probabilitas tersebut lebih kecil dibandingkan $\alpha=0,05$, hal ini berarti terdapat pengaruh yang positif dan signifikan antara perilaku kepemimpinan dan keterampilan manajerial kepala madrasah terhadap kinerja guru di MTs Negeri 1 Bolaang Mongondow Timur. ${ }^{24}$

Adapun penelitian yang dianggap relevan dengan penelitian ini adalah penelitian yang dilakukan oleh Sokhi Huda, tentang pengaruh perilaku kepemimpinan dan keterampilan manajerial kepala madrasah terhadap motivasi kerja dan kinerja guru, bahwa perilaku

24 Witran Mamonto, Pengaruh Perilaku Kepemimpinan dan Keterampilan Manajerial Kepala Madrasah terhadap Kinerja Guru di Mts Negeri 1 Bolaang Mongondow Timur, 2020, h. 68. 
kepemimpinan kepala sekolah, ketrampilan manajerial kepala sekolah, dan motivasi kerja guru secara bersamasama berpengaruh secara positif terhadap kinerja guru, dengan nilai total koefisien determinan sebesar 0,983 atau $98 \% .^{25}$

Pada hipotesis dapat dibuktikan bahwa terdapat pengaruh yang positif dan signifikan antara perilaku kepemimpinan dan keterampilan manajerial kepala madrasah dengan kinerja guru. Hal ini dipengaruhi faktor keterampilan manajerial yang tinggi sehingga dapat memperoleh pengaruh yang positif dan signifikan.

\section{Penutup}

Terdapat pengaruh yang positif dan signifikan antara perilaku kepemimpinan dan keterampilan manajerial dengan kinerja guru di MAN 1 Kotamobagu melalui uji F, nilai probabilitas dari uji $F$ yaitu nilai probabilitas (Sig) 0,025. Karena nilai probabilitas tersebut lebih kecil dibandingkan $\alpha=0,05$. Dari data di atas apabila kedua variabel independen atau bebas yakni perilaku kepemimpinan dan keterampilan manajerial digabungkan maka keduanya mampu memberikan pengaruh yang signifikan terhadap variabel dependen atau terikat yakni kinerja guru di MAN 1 Kotamobagu.

\section{Daftar Pustaka}

Ahmadi, Z. A, Kebutuhan Guru dan Tenaga Kependidikan Serta Peningkatan Kualitas Pendidikan, Jakarta: Depdikbud, 1993.

Akhtar, Hanif "Cara Membuat Kategorisasi Data Penelitian dengan Microsoft Excel," Media Elektronik, Semesta Psikometrika, 13 Juli 2020, https://www.semestapsikometrika.com/2018/02/membuat-kategori-skor-skaladengan-spss.html?m=1

Al-Khalidi Shalah Abdul Fattah, Mudah Tafsir Ibnu Katsir, Jakarta : Maghfirah Pustaka, 2016.

Arikunto, Prosedur Penelitian Suatu Pendekatan Praktik, Edisi Revisi ke IV, Jakarta : PT.Rineka Cipta, 2006..

Dharma, Surya, Manajemen Kinerja. Falsafah, Teori dan Penerapannya, Yogyakarta : Pustaka Pelajar, 2004..

Gunawan Ary H, Sosiologi Pendidikan, Jakarta : Rineka Cipta, 2010

Huda, Sokhi, Pengaruh Perilaku Kepemimpinan Dan Keterampilan Manajerial Kepala

Madrasah Terhadap Motivasi Kerja Dan Kinerja Guru, 2010. Tersedia di: https://www.google.com/url?sa=t\&rct=j\&q=\&esrc=s\&source=web\&cd=\&cad=rja\&u act=8\&ved=2ahUKEwiKtv31gYbrAhVZcCsKHR OBOIQFjABegQIAxAB\&url=htt ps\%3A\%2F\%2Fwww.researchgate.net\%2Fpublication\%2F321866815_Pengaruh_Per ilaku_Kepemimpinan_dan_Ketrampilan_Manajerial_Kepala_Sekolah_terhadap_Moti vasi_Kerja_dan_Kinerja_Guru_Laporan_Penelitian_Lapangan\&usg=AOvVaw0wkg CHJZ7ALbErzB6sg2I1, diakses pada tanggal 6 Agustus 2020, pukul 15.30 WITA.

${ }^{25}$ Sokhi Huda, pengaruh perilaku kepemimpinan dan keterampilan manajerial kepala madrasah terhadap motivasi kerja dan kinerja guru, 2010, h. 119, Tersedia di:

https://www.google.com/url?sa=t\&rct=j\&q=\&esrc=s\&source=web\&cd=\&cad=rja\&uact=8\&ved=2ahUKEwiKtv 31gYbrAhVZcCsKHR OBOIQFjABegQIAxAB\&url=https\%3A\%2F\%2Fwww.researchgate.net\%2Fpublication \%2F321866815_Pengaruh_Perilaku_Kepemimpinan_dan_Ketrampilan_Manajerial_Kepala_Sekolah_terhadap_ Motivasi_Kerja_dan_Kinerja_Guru_Laporan_Penelitian_Lapangan\&usg=AOvVaw0wkgCHJZ7ALbErzB6sg2I1 , diakses pada tanggal 6 Agustus 2020, pukul 15.30 Wita. 
Journal of Islamic Education Policy Vol. 4 No. 2 Juli - Desember 2019

Ilyas, Yaslis, Kinerja, Teori dan Penelitian, Yogyakarta : Liberty, 2005.

Mamonto, Witran, Pengaruh Perilaku Kepemimpinan dan Keterampilan Manajerial Kepala Madrasah terhadap Kinerja Guru di MTs Negeri 1 Bolaang Mongondow Timur, 2020.

Mangkunegara, Anwar Prabu. Manajemen Sumber Daya Manusia Perusahaan, Bandung : Remaja Rosda Karya, 2005.

Marno, Islam by Management and Leadership, Malang : Lintas Pustaka, 2007.

Ramayulis H, Ilmu Pendidikan Islam, Jakarta : Kalam Mulia, 2002.

Riadi, Edi. Statistika Penelitian, Yogyakarta : ANDI, 2016.

Rivai, Veithzal, Manajemen Sumber Daya Manusia Untuk Perusahaan Dari Teori ke Praktek, Jakarta : PT. Rajagrafindo Persada, 2005

Simamora, Hendry, Manajemen Sumber Daya Manusia, Yogyakarta : STIE.YKPN, 2004.

Syaodih, Nana, Metode Penelitian Pendidikan, Bandung : Remaja Rosdakarya, 2005.

Tjokrominoto, Bintoro, Pengantar Administrasi Pembangunan, Jakarta : LP3ES, 1974.

Yudiaatmaja, Fridayana, Analisis Regresi dengan Menggunakan Aplikasi Komputer Statistik Mi, Jakarta, PT Gramedia Pustaka Utama, 2013.

Yunus Mahmud, Sejarah Pendidikan Islam, Jakarta : Hidakarya Agung, 1989. 